\title{
The role of oxidative stress in activity of anticancer thiosemicarbazones
}

\author{
Katarzyna Malarz ${ }^{1,2}$, Anna Mrozek-Wilczkiewicz ${ }^{2,3}$, Maciej Serda ${ }^{1}$, Marta Rejmund ${ }^{1}$, \\ Jaroslaw Polanski ${ }^{1}$ and Robert Musiol ${ }^{1}$ \\ ${ }^{1}$ Institute of Chemistry, University of Silesia in Katowice, Katowice, Poland \\ ${ }^{2}$ Silesian Center for Education and Interdisciplinary Research, University of Silesia in Katowice, Chorzów, Poland \\ ${ }^{3}$ A. Chełkowski Institute of Physics, University of Silesia in Katowice, Katowice, Poland \\ Correspondence to: Robert Musiol, email: robert.musiol@us.edu.pl
}

Keywords: thiosemicarbazones; anticancer; iron chelators; reactive oxygen species; oxidative stress

Received: July 06, $2017 \quad$ Accepted: February 28, $2018 \quad$ Published: April 03, 2018

Copyright: Malarz et al. This is an open-access article distributed under the terms of the Creative Commons Attribution License 3.0 (CC BY 3.0), which permits unrestricted use, distribution, and reproduction in any medium, provided the original author and source are credited.

\section{ABSTRACT}

Thiosemicarbazones are chelators of transition metals such as iron or copper whose anticancer potency is intensively investigated. Although two compounds from this class have entered clinical trials, their precise mechanism of action is still unknown. Recent studies have suggested the mobilization of the iron ions from a cell, as well as the inhibition of ribonucleotide reductase, and the formation of reactive oxygen species. The complexity and vague nature of this mechanism not only impedes a more rational design of novel compounds, but also the further development of those that are highly active that are already in the preclinical phase. In the current work, a series of highly active thiosemicarbazones was studied for their antiproliferative activity in vitro. Our experiments indicate that these complexes have ionophoric properties and redox activity. They appeared to be very effective generating reactive oxygen species and deregulating the antioxidative potential of a cell. Moreover, the genes that are responsible for antioxidant capacity were considerably deregulated, which led to the induction of apoptosis and cell cycle arrest. On the other hand, good intercalating properties of the studied compounds may explain their ability to cleave DNA strands and to also poison related enzymes through the formation of reactive oxygen species. These findings may help to explain the particularly high selectivity that they have over normal cells, which generally have a stronger redox equilibrium.

\section{INTRODUCTION}

The disruption of the cellular redox homeostasis of tumor cells appears to be an attractive and promising approach for cancer therapy. Cancer cells have increased reactive oxygen species (ROS) levels compared to normal cells. This phenomenon is associated with oncogenic transformations and glycolytic metabolic adaptations, which leads to the acceleration of metabolism [1]. Thus, the high level of ROS in tumor cells renders them more susceptible to the harmful effects of the increased oxidative stress that is induced by treatment with drugs. The aforementioned effects promote the generation of ROS and/or debilitates the antioxidant system defenses in a cell [2]. This approach may be an effective strategy to eliminate abnormal cells, including colon, pancreatic, prostate and breast cancers, which are characterized by elevated basal ROS levels [3, 4]. Importantly, in cancer cells, the overexpression of P-glycoprotein and the phenomenon of multi-drug resistance (MDR) is associated with an elevated level of ROS and a modified antioxidative capacity [5]. In particular, a high level of many antioxidant proteins plays a pivotal role in the development of multidrug resistance [6].

The overproduction of ROS may affect the regulation of the expression of certain genes and proteins that are responsible for restoring the redox balance. Among them, the most important genes are those encoding manganese superoxide dismutase (MnSOD) and catalase (CAT). MnSOD is a mitochondrial protein 
that is extremely efficient in scavenging superoxide anions by converting them into hydrogen peroxide, which is further eliminated by CAT in cytosol [7, 8]. In addition, glutathione (GSH), which is the most important intracellular non-enzymatic antioxidant, plays a central role in the antioxidant system of a cell. Moreover, GSH also plays an essential role in maintaining the balance of $\mathrm{NAD}^{+} / \mathrm{NADH}, \mathrm{NADP}^{+} / \mathrm{NADPH}$ and $\mathrm{GSH} / \mathrm{GSSG}$, which characterize the cellular redox state [9]. Deregulation of the endogenous antioxidant systems, including enzymes (e.g. MnSOD and CAT) and non-enzymatic antioxidant (e.g. GSH), causes many alterations that lead to the induction of oxidative stress. Elevated oxidative stress results in the oxidation of the reduced form of GSH into glutathione disulfide (GSSG) or its conjugation with endogenous and exogenous electrophiles or efflux of glutathione from the cells. All of these mechanisms lead to an overall depletion of GSH and thus result in mitochondrial dysfunction [10-12]. Generally, oxidative stress can result in detrimental cellular damage including lipid peroxidation, DNA adduct formation, protein oxidation and enzyme inactivation, which in turn can lead to cell death through cell cycle arrest or the activation of certain transcription factors [13].

Iron and copper play a crucial role in regulating many redox processes that are essential for cell homeostasis [14]. Iron is important for cellular respiration, oxygen transport, ATP generation, the synthesis of heme and DNA [15]. Similarly, copper is responsible for enzyme activity, oxygen transport and cell signaling. Those elements, due to their low electron transfer energy, are cofactors for many redox enzymes [16, 17]. This explains the higher requirement for these essential metals that is observed in rapidly growing and proliferating neoplastic cells. Organic compounds that chelate the metal ions are able to alter the metabolism and cellular signaling pathways, which may be considered to be an attractive approach in cancer treatment.

The deprivation of iron through chelation leads to the activation of various cytotoxic mechanisms in a cell [18, 19]. Thiosemicarbazones (TSC) are a well-known class of compounds with extremely potent antitumor properties, which are associated with their ability to chelate metal ions [20-23]. The exact molecular mechanism of action of TSC is still insufficiently clear. Many reports have indicated that a multifaceted mechanism of action is possible for this class of compounds [23-26]. Namely, TSC may affect the cell cycle progression by trapping Fe and depleting the iron pool in cells, which leads to cell cycle arrest in the G1/S phase and the inhibition of ribonucleotide reductase (RR), which is an enzyme that is necessary in DNA synthesis $[27,28]$. Other studies have demonstrated that TSC can trigger apoptosis through the up-regulation of the metastasis suppressor protein, N-myc Downstream Regulated Gene 1 (Ndrg1) [29]. Furthermore, Ndrg1 expression is induced in response to various forms of cellular stress [30], which may be associated with the formation of redox-active metal complexes. Such complexes are known to produce reactive oxygen species via the Fenton reaction [23]. The latter mechanism is especially significant due to the emerging new targets in anticancer oxidative therapy, as well as its ability to increase the selective of activity of iron chelators against cancer cells [20, 23].

Currently, this class of compounds is being extensively investigated in clinical trials. In fact, the first inhibitor of RR-Triapine has completed phase II, while DpC has recently entered phase I of clinical trials (NCT02688101) [31, 32]. Among the most active TSC are compounds that are based on the dipyridylketone scaffold such as DpC, which is an analog of a firstgeneration compound - Dp44mT (Figure 1). Although both compounds have exhibited a potent and selective activity against a variety of aggressive solid tumors in vitro and in vivo, $\mathrm{DpC}$ has also demonstrated a high tolerability in vivo [23, 29, 33].

The broad investigation of TSC has led to even more active compounds with a high selectivity [34, 35]. Moreover, we reported that the relationship between the structure and activity of these compounds, in particular the presence of soft donor atoms, plays a key role in the formation of redox active iron complexes [35]. More recently, other TSC derivatives have been applied as enhancers in photodynamic therapy (PDT) [36, 37]. Moreover, it has been reported that combining the copper complexes of TSC with azines eliminates cancer cells by inducing oxidative stress [38].

Although continuous efforts have allowed many aspects of the mechanisms of the activity of TSC to be clarified, other questions have been raised as the activity of the metals appears to be more complex. Iron mobilization from cytosol has also been observed to prevent the uptake of Fe from transferrin for active compounds [39]. On the other hand, it has been reported that Dp44mT and their complexes with iron and copper cause apoptosis by generating cytotoxic ROS [23, 40]. Moreover, Akladios et al. reported that in some TSC, the addition of metal cations may increase activity [41, 42]. This observation led to the alternative use of TSC as ionophores. In fact, the structure of the metal-TSC complexes seems to be crucial for the overall ability to chelate ions as has been revealed in Triapine [43]. Thus, more comprehensive investigations are necessary to fully understand the complex molecular mechanism of action of TSC chelators [44].

In the current study, we explored the redox potency and mechanism of action of novel TSC presented in Figure 1. We selected a series of the most effective anticancer TSC that are based on dipyridylketone and quinoline from among those that have been described recently $[35,36]$. Moreover, their newly synthesized analogs and doxorubicin (DOX) were used as control. For the in vitro cytotoxicity tests, we used a colon carcinoma (HCT116) 
and a breast cancer (MCF-7) cell lines with normal human fibroblasts (NHDF) as the non-malignant control. In addition to the normal toxicity assays with iron and copper ions, the redox state in the cells was investigated. Finally, the impact of any impaired antioxidant potential on the transcription factors and cell death pathways was also examined.

\section{RESULTS}

\section{Studied compounds}

All of the structures of the investigated thiosemicarbazone derivatives that contain the quinoline, 8-hydroxyquinoline, and di-2-pyridylketone moieties are presented in Figure 1. The compounds used in this study were selected based on their ability of inhibit the growth of HCT116 p53 $3^{+/+}$cells in sub-nanomolar concentrations. Furthermore, we synthesized two novel TSC analogs $-1 \mathrm{~b}$ and $1 \mathrm{c}$.

\section{Synthesis}

The heteroaromatic TSC analogs were synthesized by reacting the respective heteroaromatic ketone or carbaldehyde and thiosemicarbazide under microwave irradiation. We applied here highly efficient microwaveassisted methodology, which was previously described by our group [35]. In general, the use of microwaves improved the purity of final compounds, providing the high assays of TSC without flash chromatography.

\section{Cytotoxicity studies}

The antiproliferative activities of all of the tested compounds against HCT116 and MCF-7 cells are presented in Table 1 as $\mathrm{IC}_{50}$ along with experiments with the increased metal ion concentrations.

Compound $3 \mathrm{a}$ was the most potent subnanomolar inhibitor in the colon cancer line followed by $3 \mathrm{~b}$ and $2 \mathrm{a}$, that were roughly as active as Dp44mT. However, 3a was also the most toxic against normal fibroblasts (NHDF). In terms of selectivity, compounds $1 \mathrm{a}, 2 \mathrm{a}$ and $2 \mathrm{~b}$ appeared to be the most useful with $2 \mathrm{a}$ having a selectivity index (for HCT116) equal to $2.8 \cdot 10^{3}$ (Supplementary Table 1). Interestingly, all of the compounds that were tested showed various patterns of activity against the MCF-7 cell line. $3 \mathrm{~b}$ was the most active while $1 \mathrm{c}$ had the highest selectivity $\left(1.0 \cdot 10^{3}\right.$ - for MCF-7).

The influence of iron on the toxicity of TSC is particularly interesting. We found that the addition of $\mathrm{Fe}^{2+}$ ions completely eliminated the activity of all of the compounds that were tested within the concentration levels (data not presented). On the other hand, in the presence of $\mathrm{Fe}^{3+}$, the TSC retained their activity against HCT116 and MCF-7 cells. At first glance, these results may seem in contrast to the literature data where Triapine and its derivatives were considerably less active when administered with $\mathrm{Fe}^{3+}$ [43]. This, however, may suggest how important the basal level of iron and ROS in cancerous cells is. We also examined the influence of copper ions on the cytotoxic effects that are induced by TSC in HCT116 and MCF-7 cells. As expected, we<smiles>[R]C(=S)N/N=C/c1ccc2ccccc2n1</smiles>

1a-c<smiles>[R]C(=S)N/N=C/c1ccc2cccc(O)c2n1</smiles>

2a-b<smiles>[R11]CCCCC([R])=S</smiles>

3a-c<smiles>CN(C)C(=S)NN=C(c1ccccn1)c1ccccn1</smiles>

Dp44mT<smiles>COc1cccc2c1C(=O)c1c(O)c3c(c(O)c1C2=O)C[C@@](O)(C(=O)CO)C[C@H]3O</smiles><smiles>CC1CC(C)OC(C)C(C)C(N)C1</smiles>

$\mathrm{HO}$

Figure 1: Structures of the studied compounds. 
observed that supplementation with this redox-active metal caused a significant increase in the cytotoxicity of the TSC. In general, we did not observe any uniform patterns of improved cytotoxicity with copper for the tested TSC in the HCT116 and MCF-7 cell lines. Nevertheless, similar to the above, compounds containing the di-2-pyridylketone moieties (3a, 3b and Dp44mT) and the 8-hydroxyquinoline derivative (2a) exhibited the highest $\mathrm{Cu}^{2+}$-dependent cytotoxicity against both cancer cell lines. On the other hand, after interacting with $\mathrm{Cu}^{2+}$, we observed the greatest improvement in cytotoxicity in the case of the $1 \mathrm{c}$ and $2 \mathrm{~b}$ compounds in HCT116 cells (more than a ten-fold increase) and for $1 \mathrm{~b}, 3 \mathrm{a}, 3 \mathrm{~b}$ (eight-fold) in MCF-7 cells.

\section{Reactive oxygen species formation - microscopic images}

To confirm the increased redox activity of the complexes with the tested compounds, we performed fluorescence imaging using CellROX, which binds to DNA upon oxidation and thus, its signal is localized primarily in the nucleus and mitochondria. The results are presented in Figure 2.
Interacting with transition metal ions may increase the ROS level in the cytosol and cause cell death. This mechanism has also been suggested for TSC [21]. All of the thiosemicarbazones that were tested increased the level of ROS significantly and were similar to hydrogen peroxide, which was used as the positive control. Additionally, after treatment with the tested compounds, we observed a strong fluorescence signal, which may primarily be focused on the mitochondria and nucleus.

\section{Time dependent measurement of ROS level}

As presented in Figure 3, the ROS level gradually rose over the time and reached the highest level after twelve hours of incubation, after which it dropped rapidly. Although this pattern was observable in all of the tested compounds, it appeared to correlate well with the activity of the TSC. Compound $3 \mathrm{a}$ had the strongest effect, followed by Dp44mT and $2 \mathrm{a}$. On the other hand, 1a-c and $3 c$ caused only a minute increase in the ROS level. This may confirm that the main aspect of the multiway mechanism of the activity TSC relies on the Fenton and Haber-Weiss reactions.

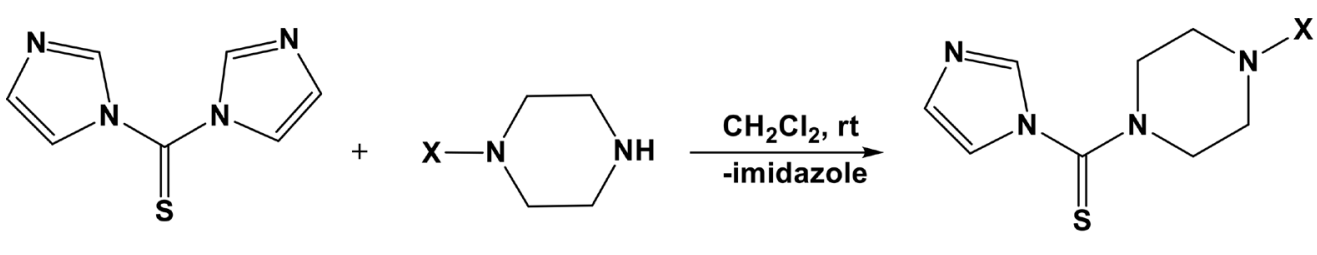

$\mathrm{X}=$ alkyl, aryl<smiles>S=C(N1CCCCC1)n1ccnc1</smiles>

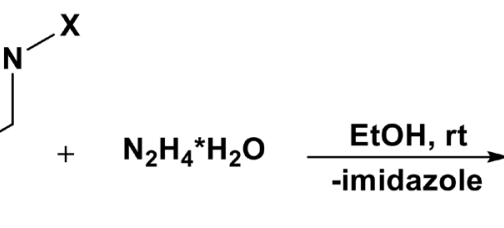<smiles>[X]N1CCN(C(=S)NN)CC1</smiles>

$X=$ alkyl, aryl<smiles>[R3]NC(=S)NN</smiles><smiles>CCOC(=O)O</smiles><smiles>[R]NC(=S)NN=C([R])[R]</smiles>

$\mathrm{R}_{1}=$ quinoline, 8-hydroxyquinoline, pyridine $R_{2}=H$, pyridine

$\mathbf{R}_{\mathbf{3}}=$ substituted piperazine

Scheme 1: General method for synthesis of studied TSC. 
Table 1: Antiproliferative activity of the studied compounds

\begin{tabular}{|c|c|c|c|c|c|c|c|c|}
\hline \multirow{2}{*}{ Comp. } & \multirow{2}{*}{$\mathbf{R}$} & \multicolumn{7}{|c|}{ Activity $-\mathrm{IC}_{50}[\mathrm{nM}]$} \\
\hline & & HCT116 & $\mathrm{HCT116}+\mathrm{Cu}^{2+}$ & $\mathrm{HCT} 116+\mathrm{Fe}^{3+}$ & MCF-7 & $\mathrm{MCF}-7+\mathrm{Cu}^{2+}$ & MCF-7+ $\mathrm{Fe}^{3+}$ & NHDF \\
\hline 1a & & $87.70 \pm 43.86^{\mathrm{a}}$ & $59.57 \pm 6.45$ & $96.91 \pm 16.92$ & $219.00 \pm 15.10$ & $44.90 \pm 3.77$ & $273.40 \pm 35.65$ & $9.44 \cdot 10^{3} \pm 3.84 \cdot 10^{3 a}$ \\
\hline $1 \mathrm{~b}$ & & $62.21 \pm 8.95$ & $19.67 \pm 0.53$ & $72.37 \pm 12.90$ & $31.39 \pm 3.38$ & $3.78 \pm 0.88$ & $24.97 \pm 2.16$ & $114.40 \pm 10.30$ \\
\hline $1 \mathrm{c}$ & & $72.14 \pm 9.40$ & $7.19 \pm 1.84$ & $70.81 \pm 7.28$ & $17.25 \pm 2.71$ & $4.48 \pm 1.18$ & $39.13 \pm 6.51$ & $17.07 \cdot 10^{3} \pm 1.41 \cdot 10^{3}$ \\
\hline $2 \mathrm{a}$ & -1 & $3.84 \pm 1.46^{\mathrm{a}}$ & $1.39 \pm 0.44$ & $7.57 \pm 1.19$ & $10.87 \pm 2.85$ & $2.39 \pm 0.42$ & $8.83 \pm 1.29$ & $10.64 \cdot 10^{3} \pm 3.48 \cdot 10^{3 a}$ \\
\hline $2 b$ & & $50.50 \pm 28.10^{\mathrm{a}}$ & $4.17 \pm 1.12$ & $78.16 \pm 14.00$ & $32.23 \pm 6.85$ & $5.49 \pm 1.19$ & $35.83 \pm 5.82$ & $12.14 \cdot 10^{3} \pm 3.58 \cdot 10^{3 a}$ \\
\hline $3 a$ & & $0.81 \pm 0.13^{\mathrm{a}}$ & $0.68 \pm 0.15$ & $2.07 \pm 0.78$ & $11.98 \pm 2.04$ & $1.55 \pm 0.55$ & $8.96 \pm 1.81$ & $1.73 \pm 0.71^{\mathrm{a}}$ \\
\hline $3 b$ & 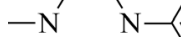 & $2.06 \pm 0.88^{\mathrm{a}}$ & $1.56 \pm 0.44$ & $9.94 \pm 2.69$ & $4.10 \pm 0.93$ & $0.54 \pm 0.15$ & $5.35 \pm 0.66$ & $160.00 \pm 40.00^{\mathrm{a}}$ \\
\hline $3 \mathrm{c}$ & -1 & $37.80 \pm 3.05^{\mathrm{a}}$ & $4.95 \pm 1.64$ & $29.53 \pm 3.69$ & $25.60 \pm 6.74$ & $4.41 \pm 1.50$ & $16.58 \pm 2.25$ & $13.85 \pm 0.03^{\mathrm{a}}$ \\
\hline Dp44mT & - & $1.40 \pm 0.13^{\mathrm{a}}$ & $0.31 \pm 0.06$ & $1.77 \pm 0.36$ & $0.38 \pm 0.15$ & $0.13 \pm 0.04$ & $0.96 \pm 0.32$ & $15.38 \cdot 10^{3} \pm 5.06 \cdot 10^{3 a}$ \\
\hline DOX & - & $91.00 \pm 6.96$ & $62.50 \pm 8.24$ & $84.84 \pm 11.22$ & $404.90 \pm 38.00$ & $335.60 \pm 65.35$ & $413.60 \pm 59.05$ & $137.00 \pm 26.00$ \\
\hline
\end{tabular}

${ }^{a}$ data from [35].

\section{Time dependent measurement of glutathione level}

Previous results prompted us to study the influence of the tested TSC on the GSH level. We performed experiments in the same conditions (as for the ROS level), but this time the concentration of the natural antioxidant (GSH) was measured. Results are shown in Figure 4.

A high level of ROS led to the oxidation of glutathione and diminished the overall antioxidative potential in a cell. Time-dependent changes in the GSH level confirmed the increased vulnerability of the cells to ROS-dependent damage. This in turn prompted us to evaluate the gene expression under the oxidative stress that was induced by the TSC.

\section{The antioxidative genes expression}

The antioxidative genes concentration levels are presented in Figure 5.
In general, most of the tested TSC caused a decrease in the expression of MnSOD (Figure 5) progressing with incubation time, except of 2a, where slight increase can be noticed. For compound 1a however, after the initial decline (for $12 \mathrm{~h}$ ) there is a small increase in expression of MnSOD. In the case of catalase, the effect was strongly dependent on time as its level was higher for the active compounds $(2 \mathrm{~b}, 3 \mathrm{a}, 3 \mathrm{~b}, 1 \mathrm{c})$ after the first $12 \mathrm{~h}$. Then, after the next $12 \mathrm{~h}$, it decreased dramatically for all of the thiosemicarbazones that were tested. This downregulation of MnSOD and CAT could be explained by the interruption in the cellular oxidative equilibrium towards the induction of strong oxidative stress. The level of ROS is so high, that mechanisms responsible for protecting the cell collapsed. Therefore, leading to trigger the pathways involved in the cell death. One of the factors engaged in the apoptosis induction is Ndrg1 protein. As is shown in the Figure 5 the Ndrg1 gene level rose considerably after $24 \mathrm{~h}$ of incubation with the TSC. This effect was the 
strongest for $2 \mathrm{~b}, 3 \mathrm{~b}$, and $3 \mathrm{c}$. We also observed significant increase for $3 \mathrm{a}$, but after $12 \mathrm{~h}$. These results indicate that the cell entered on the apoptosis pathway [45].

\section{Western blot analysis of the cell cycle and apoptosis proteins}

Antioxidant genes expression indicated that tested TSC influenced the ROS generation in cell. This prompted us to carry out further studies designed to reveal proteins responsible for cell cycle and death. As is shown on Figure 6 we explored p21, p53, and cdc2 proteins. We observed no influence on the p53 among all of the tested compounds, except DOX. Densitometric analysis of proteins indicated a marked up-regulation of p21 after incubation with 1c, 3c and Dp44mT (Figure 6B). For compounds $1 \mathrm{~b}$, and $3 \mathrm{~b}$ we also noticed the increased p21 level, but in a lesser degree. In the case of cdc2 we detected a significant growth just for $3 \mathrm{a}$. For the rest of the tested compounds we register down-regulation, which takes the lowest values for Dp44mT and $1 \mathrm{~b}$.

\section{Cell cycle assay}

We examined the effect of the tested TSC and DOX on the regulation of the cell cycle in HCT116 cells after $48 \mathrm{~h}$ of incubation (Figure 7). Generally, we observed a significant decrease in the percentage of cells in the G0/ G1 phase after treatment with all of the tested compounds. Specifically, one of the most active compounds $3 \mathrm{~b}$ diminished the cell count in the G0/G1 phase to $39 \%$ compared to the untreated cells (72\%) (Figure 7B). Additionally, all of the TSC caused a significant increase of the fraction cells in the $\mathrm{S}$ phase of the cell cycle. In general, some differences after treatment with the compounds in series 1, 2 and 3 were observed. The compounds of $1 \mathrm{a}-\mathrm{c}$ and $3 \mathrm{~b}-\mathrm{c}$ showed a significant increase in this proportion of cells of $40-48 \%$. These results were comparable to those of Dp44mT (41\%), while in the case of $2 \mathrm{a}, 2 \mathrm{~b}$ and $3 \mathrm{a}$, smaller effect was observed (33-35\%). Thus, all of these data suggest that TSC may also induce cell death through the cell cycle arrest in the $\mathrm{S}$ and $\mathrm{G} 2 / \mathrm{M}$ phases. For example, the compounds in series 2 and
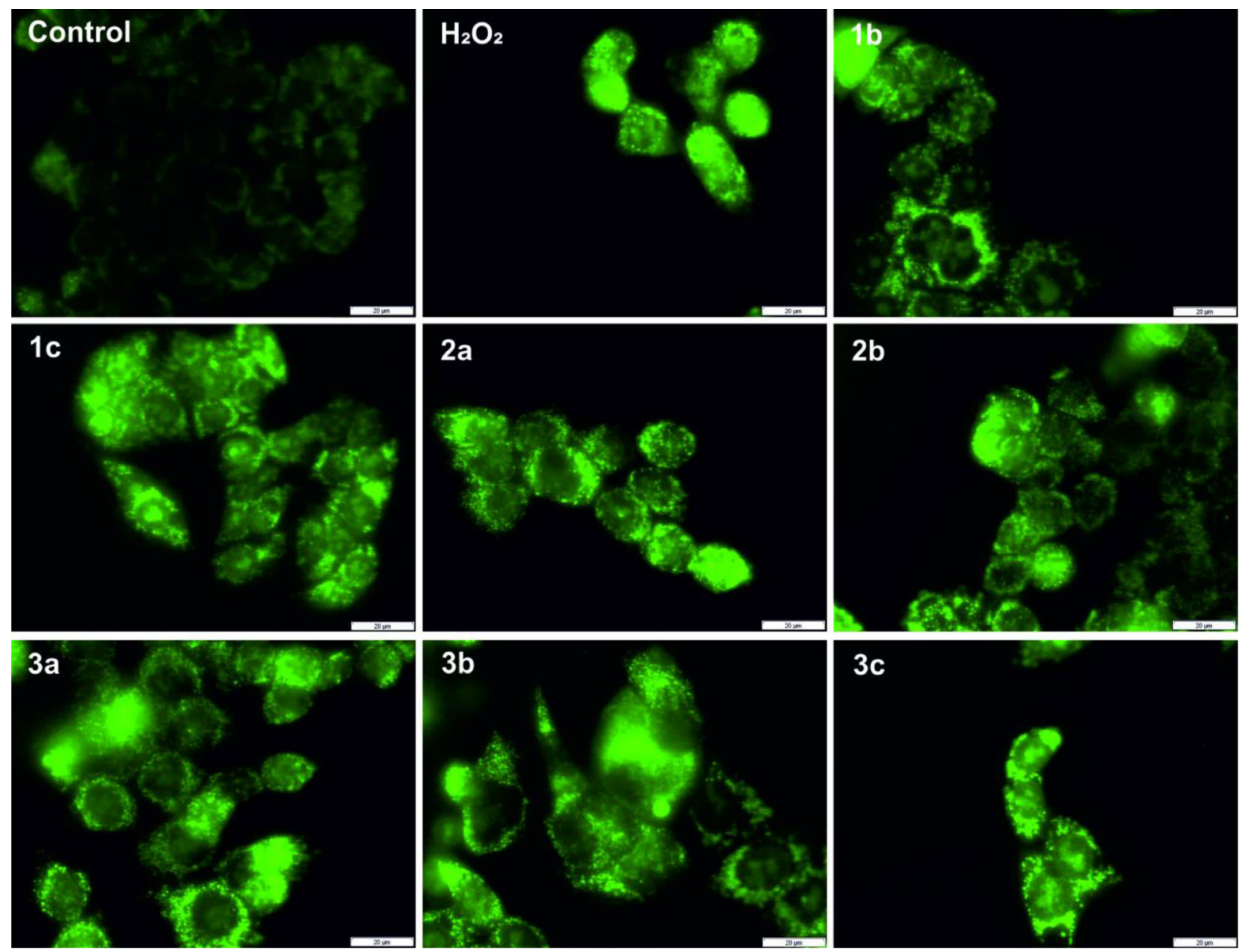

Figure 2: Formation of reactive oxygen species in HCT116 cells after $24 \mathrm{~h}$ treatment with the tested compounds (concentration $\left.2 \times \mathrm{IC}_{50}\right)$ and a 15 -min incubation with hydrogen peroxide $(100 \mu \mathrm{M})$, which was used as the positive control. The negative control consisted of untreated cells. Scale bars $=20 \mu \mathrm{m}$. 
$1 \mathrm{a}$

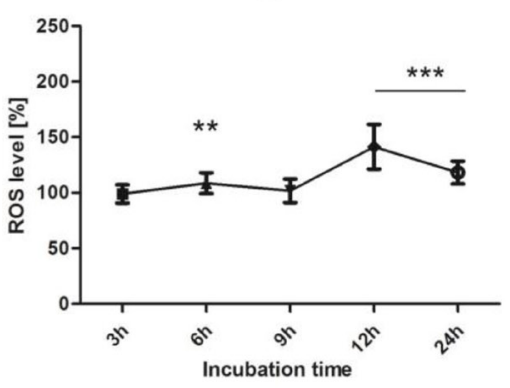

1c

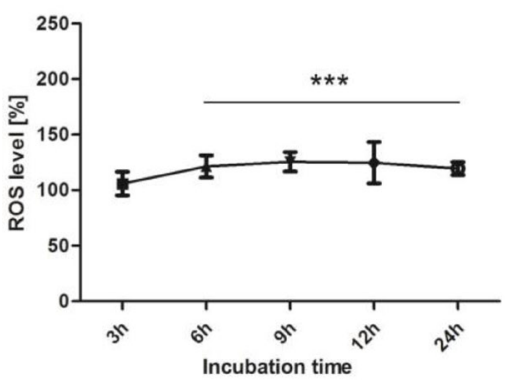

$2 b$

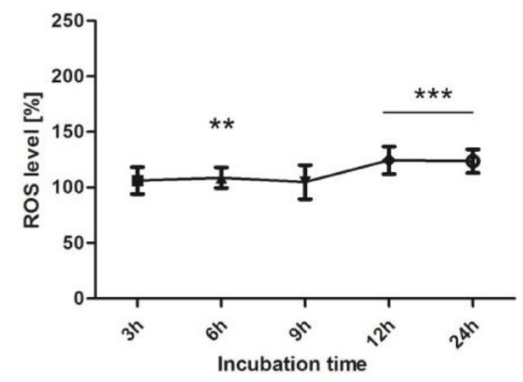

$3 b$

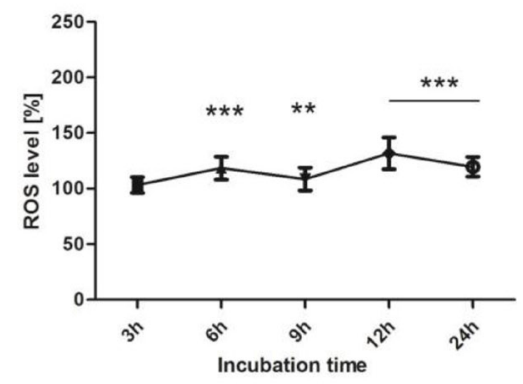

Dp44mT

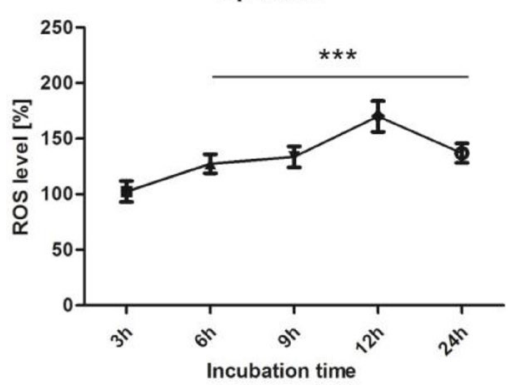

$1 b$

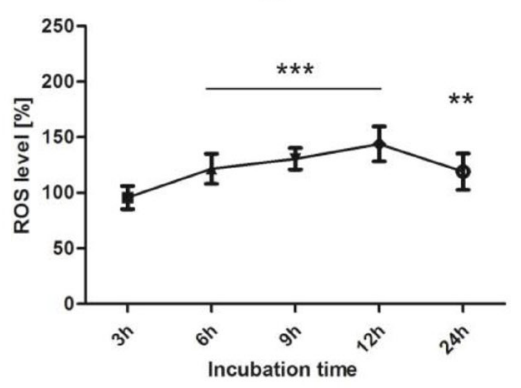

2a

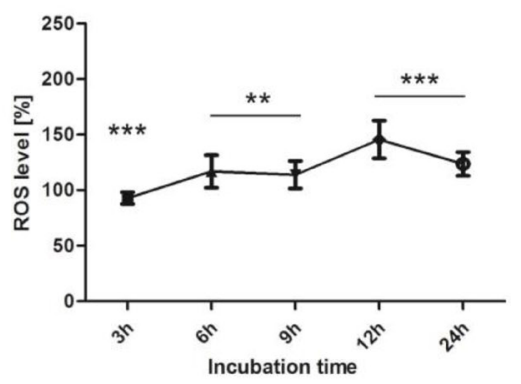

$3 a$

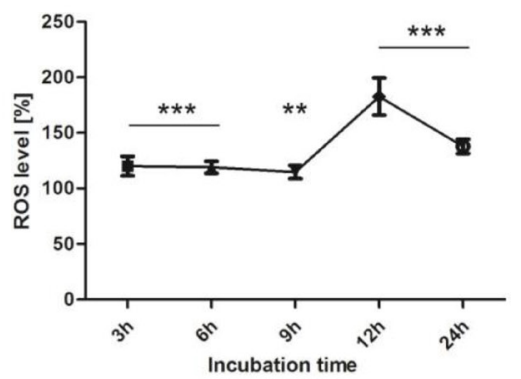

$3 c$

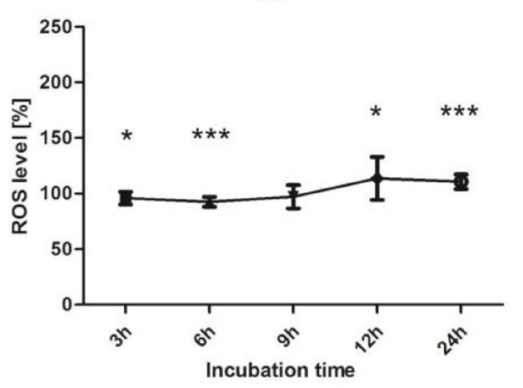

DOX

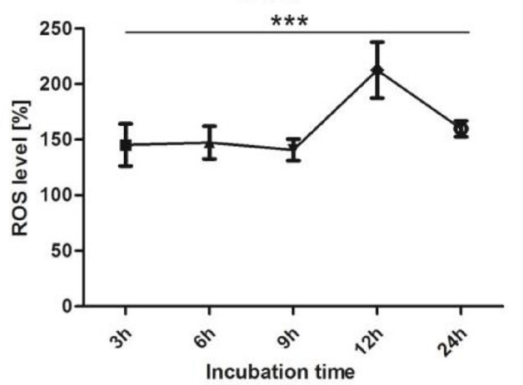

Figure 3: Effect of the tested compounds $(1 \mu \mathrm{M})$ and DOX $(5 \mu \mathrm{M})$ on the level of ROS in HCT116 cells. Data normalized to untreated cells (control). Results are shown as the mean \pm SD of three independent measurements. Data were analyzed using the Student's $t$-test: ${ }^{*} p<0.05,{ }^{* *} p<0.01,{ }^{* * *} p<0.001$ compared to the control group. 
$1 \mathrm{a}$

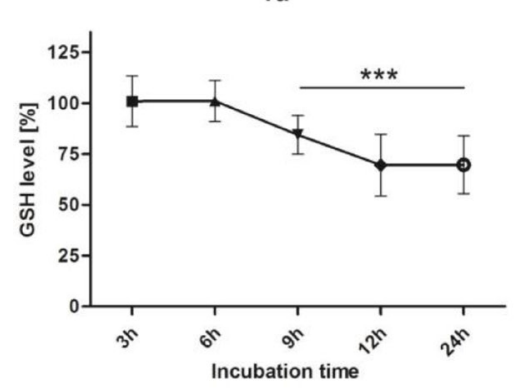

1c

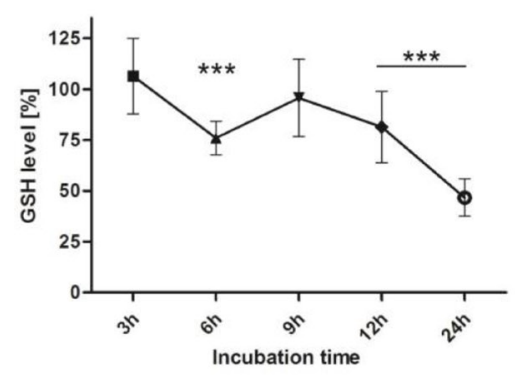

2b

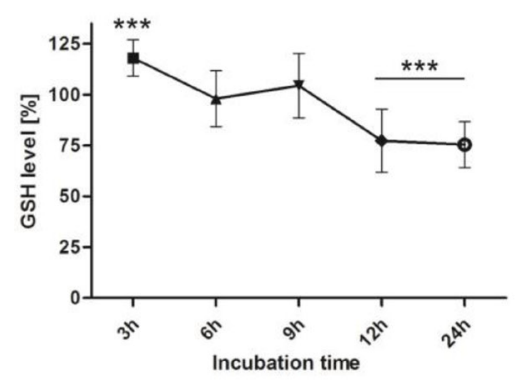

$3 b$
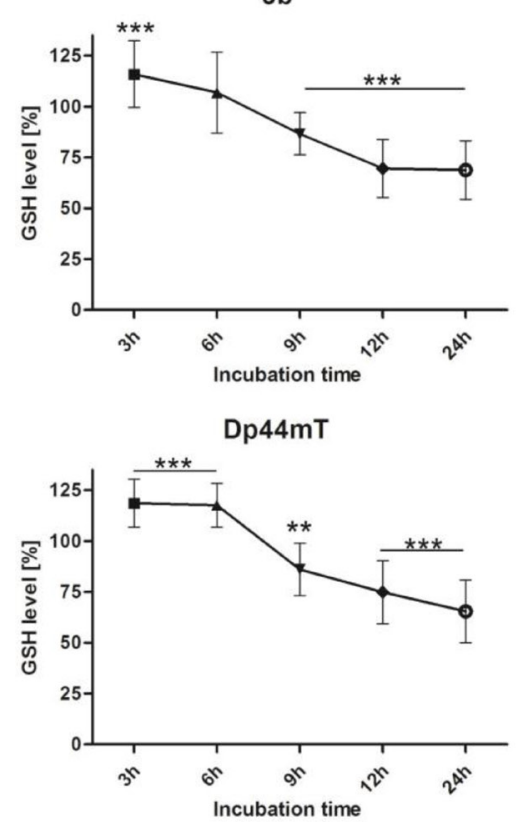

$1 b$

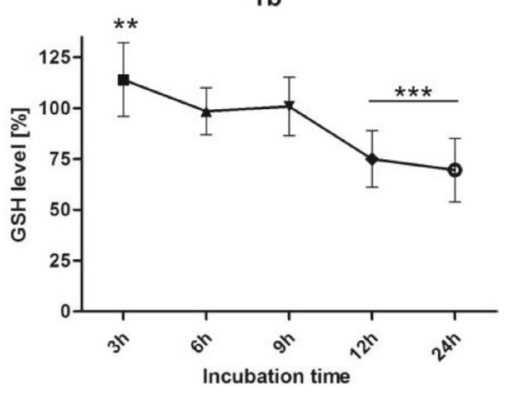

2a

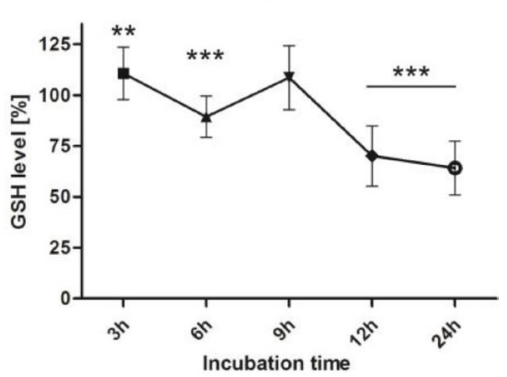

$3 a$

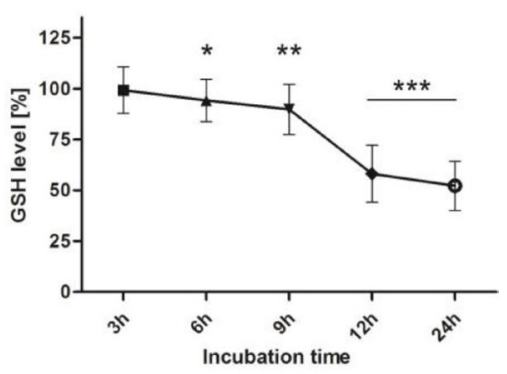

3c

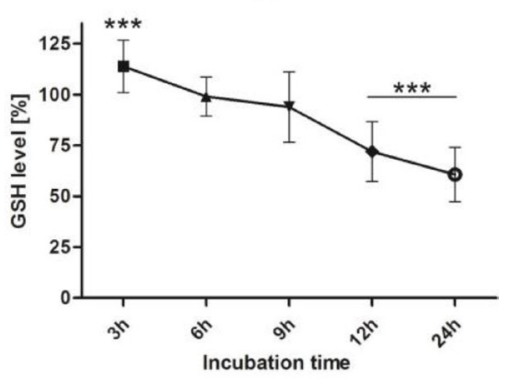

DOX

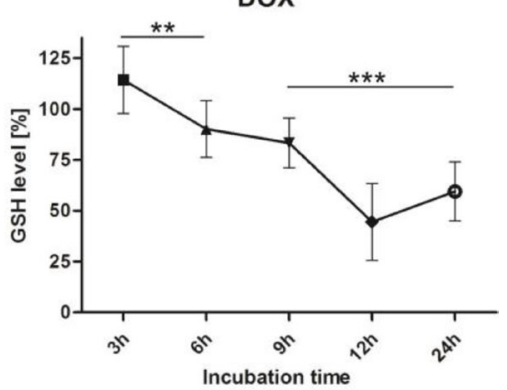

Figure 4: Effect of the tested compounds $(1 \mu \mathrm{M})$ and DOX $(5 \mu \mathrm{M})$ on the intracellular GSH content of HCT116 cells. Data normalized to the untreated cells (control). Results are shown as the mean \pm SD of three independent measurements. Data were analyzed using the Student's $t$-test: ${ }^{*} p<0.05,{ }^{* *} p<0.01,{ }^{* * *} p<0.001$ compared to the control group. 
compound $3 \mathrm{a}$ caused an increase in the cell count in the $\mathrm{G} 2 / \mathrm{M}$ phase to $17 \%$ compared to the untreated cells $(7 \%)$ (Figure 7B).

\section{Annexin $\mathrm{V}$ binding assay}

The evaluation of apoptosis in the HCT116 cell line was confirmed using Annexin V staining. Results are presented in Figure 8.

As is presented in Figure 8, a significantly increased population of total apoptotic cells after treatment with tested the compounds can be observed. Moreover, the strongest effect was observed for 1c, 3c, Dp44mT and DOX, which correlates with their ability to significantly up-regulate the p21 protein. In the case of the $2 a-b$ compounds, the lowest proportion of apoptotic cells was observed, which may be associated with a late entry into apoptosis or undergoing a mitotic catastrophe. In this case, a higher chelation ability and the disruption of the antioxidant potential of a cell may be connected with a stronger obstructive effect on cell cycle progression and a lower overall apoptotic cell count.

\section{Intercalation}

Further, we studied the ability of tested thiosemicarbazone derivatives to bind DNA strains. The absorption spectra of the tested compounds in the absence and presence of calf-thymus DNA, which is presented in
Figure 9 and Table 2, summarize the absorption spectral properties of the tested thiosemicarbazones. Our results indicate that DNA intercalation is strongly possible in the tested TSC, which results in a decrease in band intensities and a small shift of the wavelength. These changes in the band intensities of the spectra (hypochromism) are caused by the contraction of the DNA helix axes and also from the conformational changes on the molecules of DNA [46]. TSC (3a-c) with a fragment of dipyridyl ketone revealed the strongest hypochromism of about $28.2 \%, 31.9 \%$ and $28.5 \%$, respectively. These values are similar to the reference - doxorubicin, which is a well-characterized DNA-intercalation drug [47]. In our experiments, we observed a significant decrease in the absorption intensity of about $34.2 \%$ for doxorubicin. Interestingly, Dp44mT showed a very weak ability to intercalate DNA, which has also been confirmed by other groups [23, 48]. However, thiosemicarbazones 1a-c, which are based on the quinoline moiety, showed good intercalation properties and strong hypochromism of about $22.0 \%, 24.2 \%$ and $22.6 \%$, respectively, was observed.

\section{DISCUSSION}

Dipyridyl- and quinolinyl-based TSC are among the most potent antiproliferative compounds of this class [23]. Among them, we recently identified a series of derivatives that appeared to be thousands of times more effective than Triapine against several human cancer cell

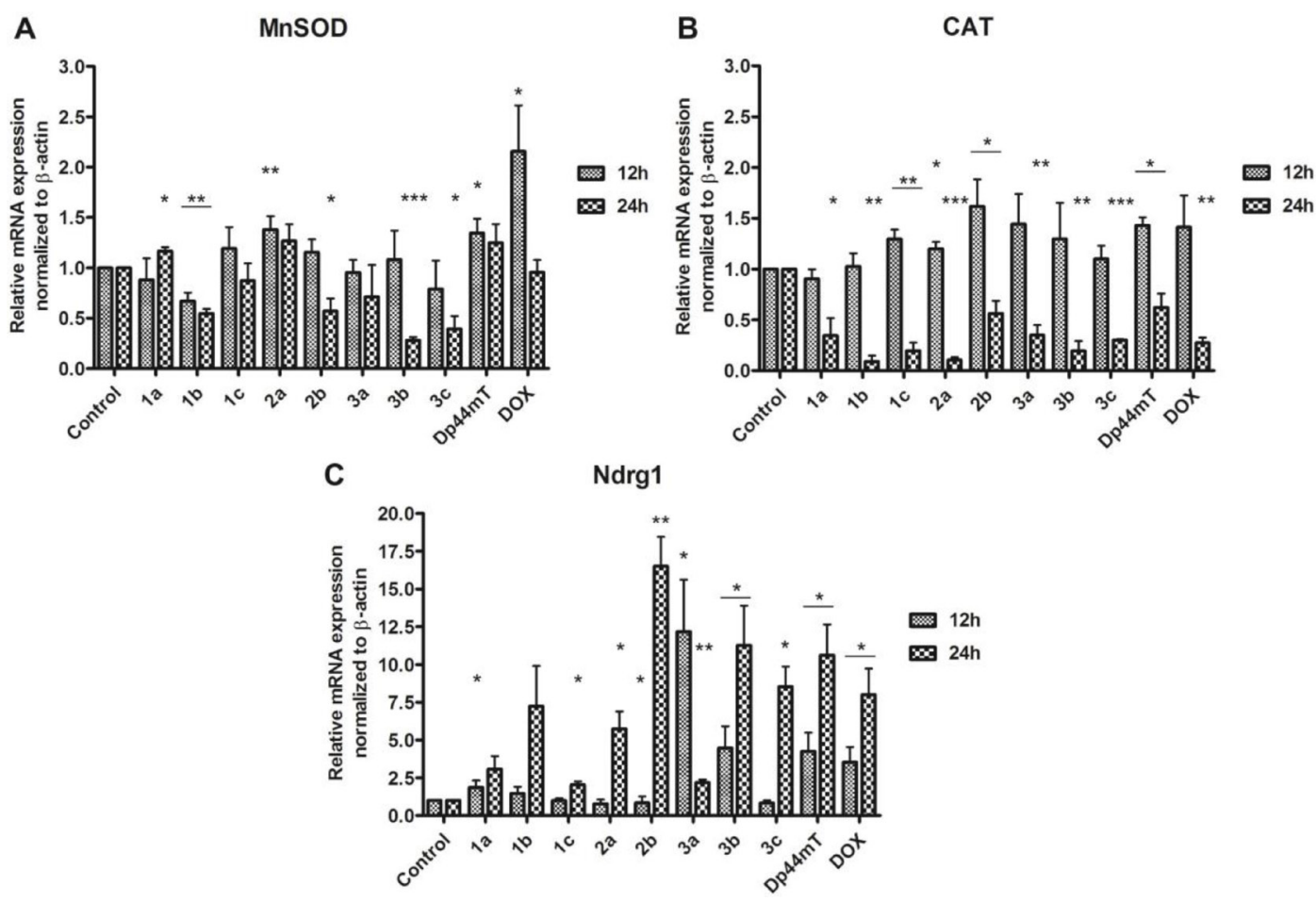

Figure 5: mRNA expression of MnSOD, CAT and Ndrg1 in the HCT116 cell line after incubation with TSC (1 $\mu$ M) and doxorubicin $(\mathbf{5} \boldsymbol{\mu M})$. Results are shown as the mean $\pm \mathrm{SD}$ of three independent measurements, each in triplicate. Data were analyzed using the Student's $t$-test: ${ }^{*} p<0.05,{ }^{* *} p<0.01,{ }^{* * *} p<0.001$ compared to the control (untreated cells). 
lines [35]. In this paper we present several compounds, which possess strong anticancer activity $(1 \mathrm{a}, 2 \mathrm{~b}, 3 \mathrm{a}$, $3 b)$, and a promising selectivity index. Antiproliferative activity of these compounds was investigated along with apparent mechanism of action. In general TSC can be regarded as metal chelators. According to the hypothesis presented by Ding and Lind metal chelating compound can be classified as chelator, metal shuttle or ionophore regarding to the intrinsic mechanism of action [50]. This can be distinguished by testing the activity changes in metal overload or complexes. For TSC however series of complexes were synthesized and tested providing ambiguous results [51]. Both the increase [21] and decrease [23] of activity have been reported for various complexes. For active compounds, that are tested in much smaller concentrations than metal ions, the ionophoric mode (ligand transports multiple ions through membranes) seems to be predisposed [40, 52, 53]. To test the ionophore hypothesis, we studied the influence of metal ions on the cytotoxicity of the TSC. Human colon cells and breast cancers are particularly suitable for this study because of their higher sensitivity to an increased ROS level due to their higher basal level [54]. Both of the cell lines (HCT116 and MCF-7) used in this study are also known for their the relatively high level of iron and iron-regulatory proteins [55-57]. Moreover, drugs that impair the level of cellular iron were found to be less vulnerable to resistance in these cells $[58,59]$. All of the TSC that were tested are potent iron chelators that are able to change the iron concentration within a cell [34, 35]. The overall cytotoxic effect, however, depends on the cells susceptibility to changes in the iron and ROS levels. Similar differences have been described for the leukemia [60], neuroepithelioma [23] and neuroblastoma [61] cell lines. In the case of copper ions we observed even higher increase of the activity. One explanation for these observations may be the different chelating ability of tested TSC, as we suggested in the case of iron. Moreover cancer cells are more sensitive for the change of the $\mathrm{Cu}^{2+}$ level as basal level of this metal is elevated, particularly in prostate and breast cancers [62]. Copper chelators with ionophoric activity are known for their promising potency and selectivity towards cancer cells. An example of such compounds studied in clinical trials is clioquinol or bisthiosemicarbazone [16]. However the exact mechanism of their activity is not clarified, they tend
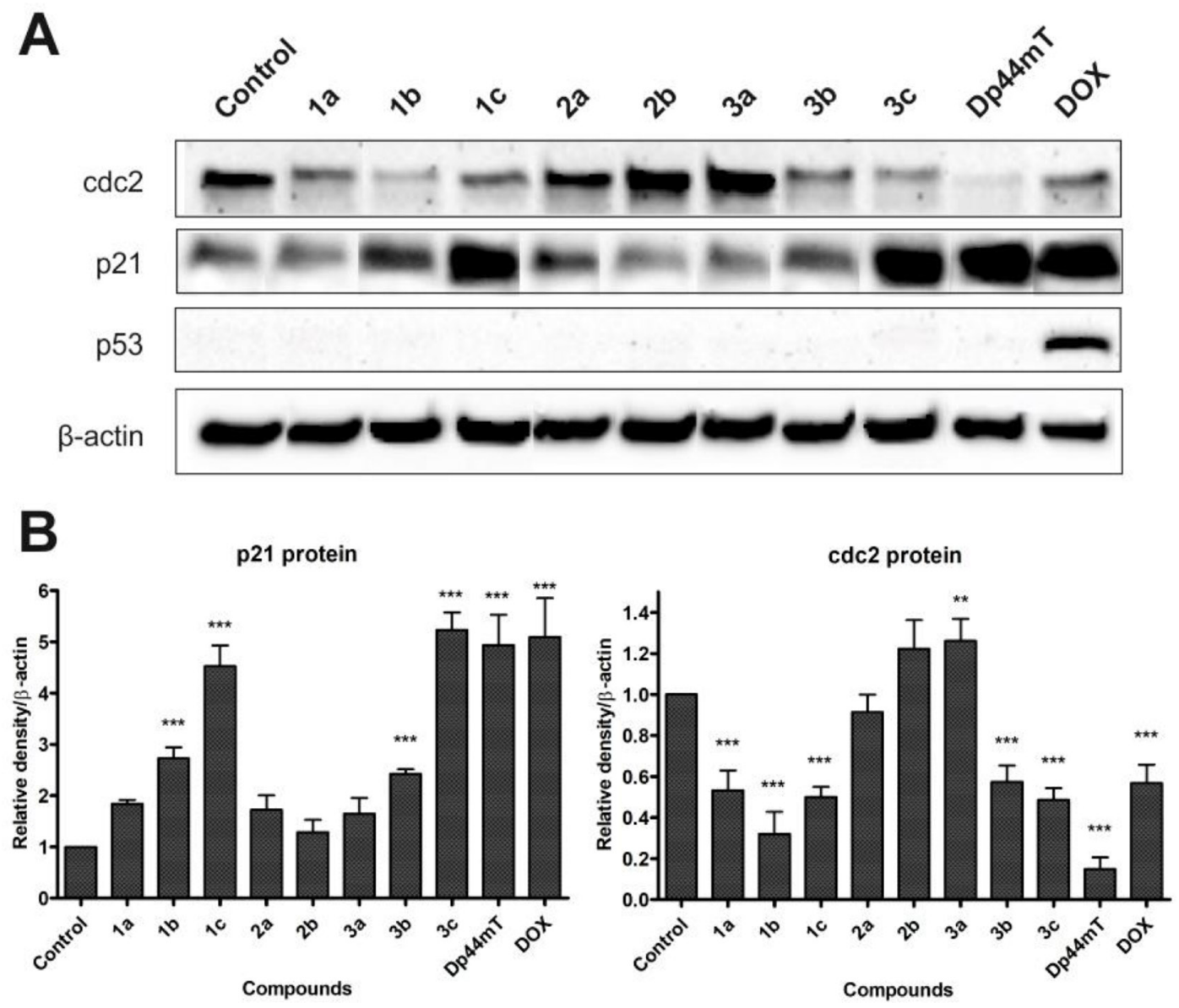

Figure 6: Influence of the tested compounds $(1 \mu \mathrm{M})$ and DOX $(5 \mu \mathrm{M})$ on the expression of cdc2, p21, p53 and $\beta$-actin in HCT116 cells (A). Data for $\mathrm{p} 21$ and cdc2 were analyzed using one-way ANOVA with Bonferroni's post-hoc test: ${ }^{*} p<0.05,{ }^{* *} p<0.01,{ }^{* * *} p<0.001$ compared to the control (B). 
A

Control

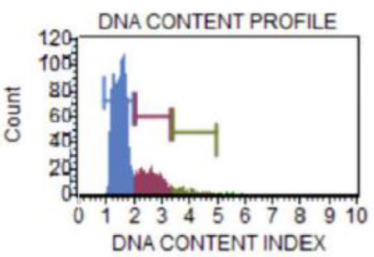

$2 \mathrm{a}$

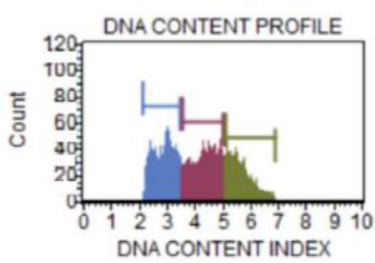

3c

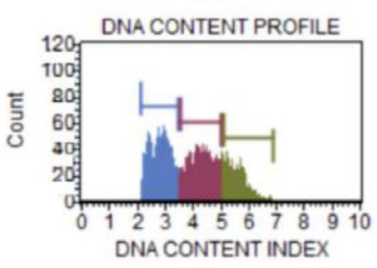

1a

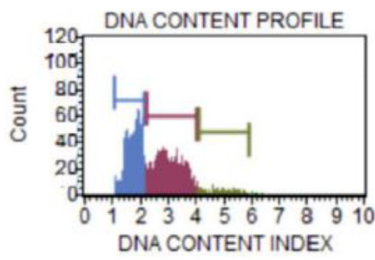

2b

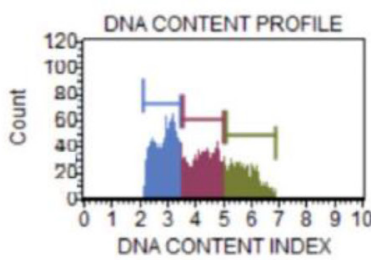

Dp44mT

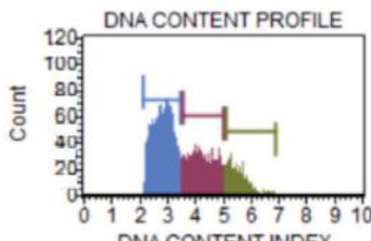

1b

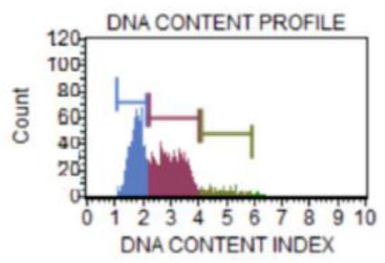

$3 a$

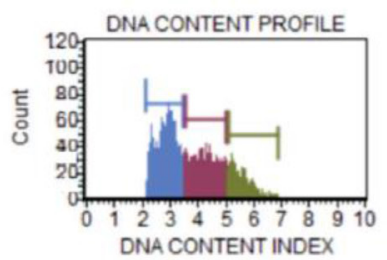

DOX

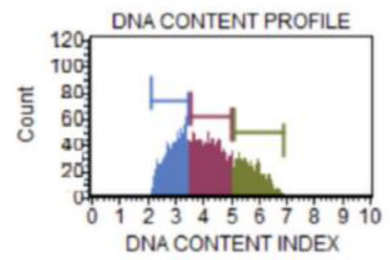

1c

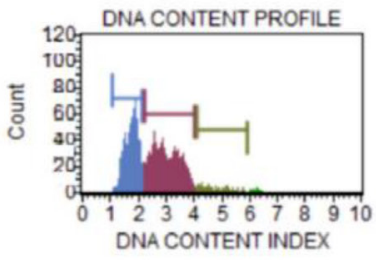

$3 b$

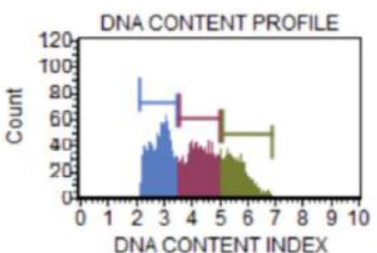

B

\begin{tabular}{|c|c|c|c|c|c|c|c|c|c|c|c|}
\hline & Control & 1a & 1b & 1c & 2a & 2b & 3a & 3b & 3c & Dp44mT & DOX \\
\hline $\begin{array}{c}\text { G0/G1 } \\
\text { [\%] }\end{array}$ & $\begin{array}{c}72.31 \pm \\
8.31\end{array}$ & $\begin{array}{c}45.05 \pm \\
1.20\end{array}$ & $\begin{array}{c}42.77 \pm \\
2.53\end{array}$ & $\begin{array}{c}41.50 \pm \\
2.55\end{array}$ & $\begin{array}{c}49.27 \pm \\
11.76\end{array}$ & $\begin{array}{c}46.30 \pm \\
5.52\end{array}$ & $\begin{array}{c}48.97 \pm \\
5.08\end{array}$ & $\begin{array}{c}39.70 \pm \\
6.06\end{array}$ & $\begin{array}{c}42.35 \pm \\
5.49\end{array}$ & $\begin{array}{c}46.07 \pm \\
6.09\end{array}$ & $\begin{array}{c}39.50 \pm \\
13.07\end{array}$ \\
\hline $\mathbf{S}[\%]$ & $\begin{array}{c}19.82 \pm \\
8.97\end{array}$ & $\begin{array}{c}40.90 \pm \\
9.76\end{array}$ & $\begin{array}{c}42.27 \pm \\
6.94\end{array}$ & $\begin{array}{c}48.65 \pm \\
5.59\end{array}$ & $\begin{array}{c}33.27 \pm \\
8.39\end{array}$ & $\begin{array}{c}35.85 \pm \\
2.90\end{array}$ & $\begin{array}{c}35.10 \pm \\
0.46\end{array}$ & $\begin{array}{c}42.80 \pm \\
10.75\end{array}$ & $\begin{array}{c}43.17 \pm \\
9.29\end{array}$ & $\begin{array}{c}41.03 \pm \\
9.71\end{array}$ & $\begin{array}{c}46.80 \pm \\
14.44\end{array}$ \\
\hline $\begin{array}{c}\mathbf{G} 2 / \mathbf{M} \\
\text { [\%] }\end{array}$ & $\begin{array}{c}7.23 \pm \\
0.93\end{array}$ & $\begin{array}{c}13.70 \pm \\
9.05\end{array}$ & $\begin{array}{c}11.01 \pm \\
3.96\end{array}$ & $\begin{array}{c}8.30 \pm \\
2.69\end{array}$ & $\begin{array}{c}16.90 \pm \\
9.10\end{array}$ & $\begin{array}{c}17.25 \pm \\
9.12\end{array}$ & $\begin{array}{c}17.65 \pm \\
4.65\end{array}$ & $\begin{array}{c}13.35 \pm \\
5.30\end{array}$ & $\begin{array}{c}13.87 \pm \\
6.40\end{array}$ & $\begin{array}{c}12.40 \pm \\
6.44\end{array}$ & $\begin{array}{c}13.03 \pm \\
9.05\end{array}$ \\
\hline
\end{tabular}

C

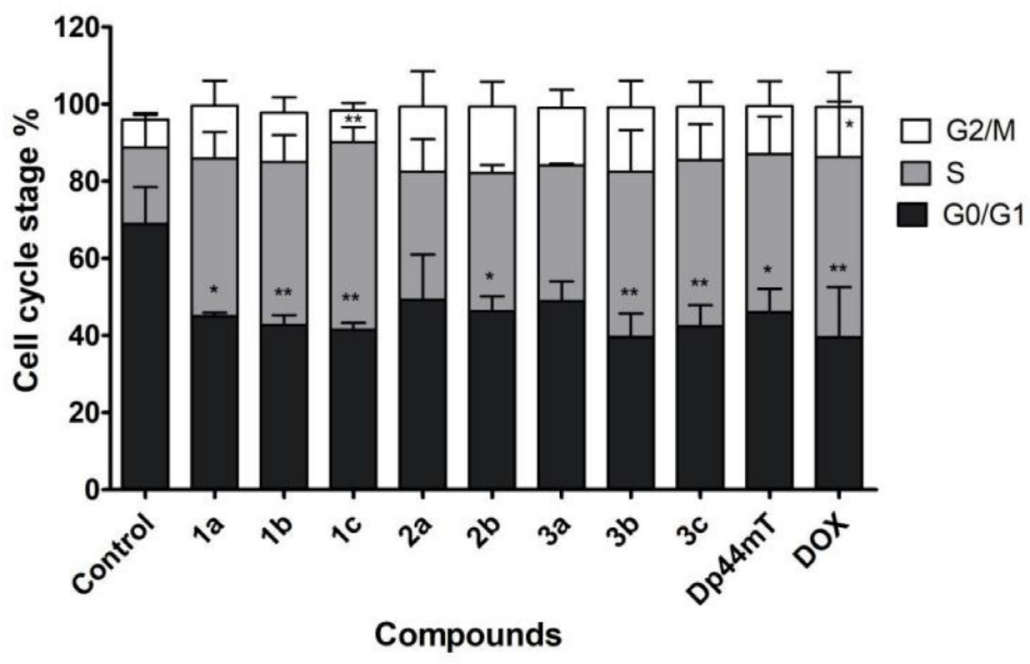

Figure 7: Impact of TSC $(1 \mu \mathrm{M})$ and DOX $(5 \mu \mathrm{M})$ treatment on the regulation of the cell cycle in HCT116 cells. The histograms show the distribution of cells in the G0/G1, S and G2/M phases of the cell cycle for one of the experiments (A). The table shows the mean \pm SD percentage of cells in the G0/G1, S and G2/M phases of the cell cycle from three independent experiments (B). Data were analyzed using one-way ANOVA with Bonferroni's post-hoc test: ${ }^{*} p<0.05,{ }^{* *} p<0.01,{ }^{* * *} p<0.001$ compared to the control (C). 
A

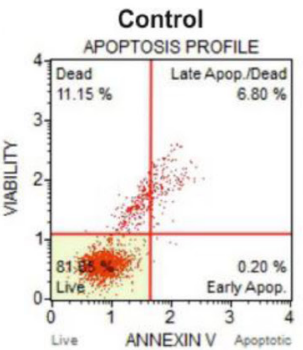

2a

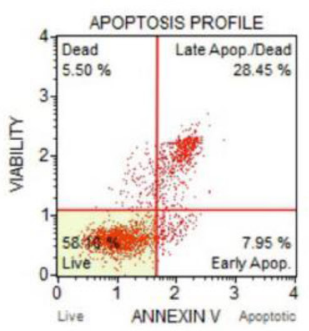

3c

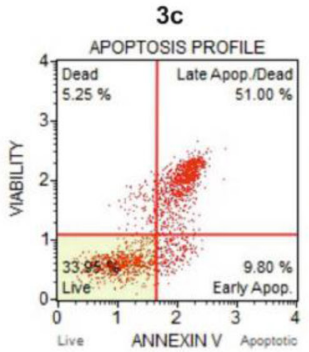

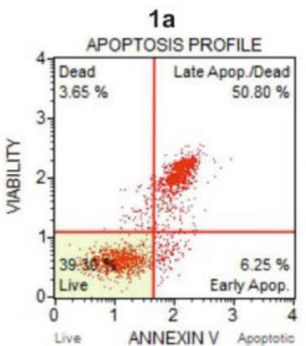

$2 b$

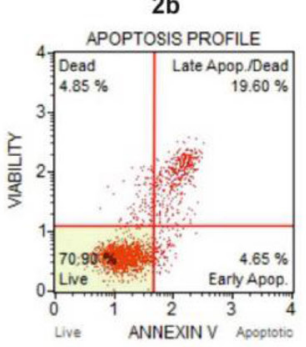

Dp44mT

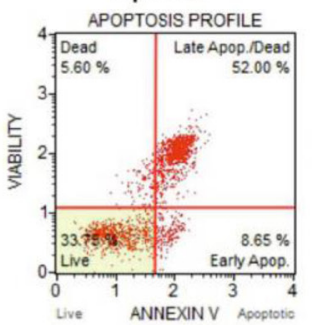

$1 \mathrm{~b}$

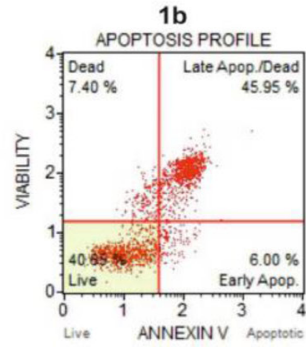

$3 a$

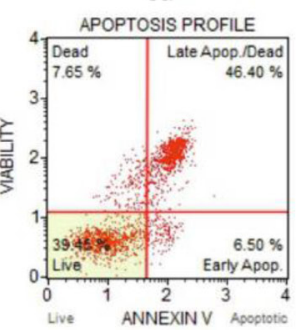

DOX

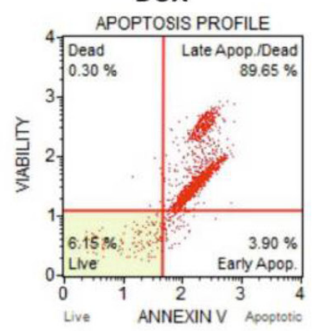

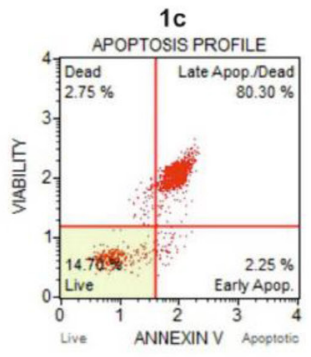

3b

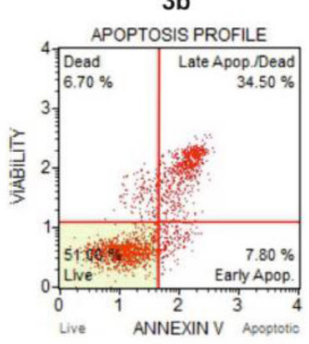

B

\begin{tabular}{|c|c|c|c|c|c|c|c|c|c|c|c|}
\hline & Control & $\mathbf{1 a}$ & $\mathbf{1 b}$ & $\mathbf{1 c}$ & $\mathbf{2 a}$ & $\mathbf{2 b}$ & $\mathbf{3 a}$ & $\mathbf{3 b}$ & $\mathbf{3 c}$ & $\mathbf{D p 4 4 m T}$ & $\mathbf{D O X}$ \\
\hline Live [\%] & $\begin{array}{c}84.99 \pm \\
3.32\end{array}$ & $\begin{array}{c}46.45 \pm \\
10.11\end{array}$ & $\begin{array}{c}37.05 \pm \\
5.10\end{array}$ & $\begin{array}{c}15.93 \pm \\
1.73\end{array}$ & $\begin{array}{c}67.05 \pm \\
12.65\end{array}$ & $\begin{array}{c}77.65 \pm \\
9.55\end{array}$ & $\begin{array}{c}48.99 \pm \\
13.48\end{array}$ & $\begin{array}{c}47.60 \pm \\
4.81\end{array}$ & $\begin{array}{c}32.87 \pm \\
1.53\end{array}$ & $\begin{array}{c}31.35 \pm \\
3.40\end{array}$ & $\begin{array}{c}8.98 \pm \\
4.00\end{array}$ \\
\hline $\begin{array}{c}\text { Total } \\
\text { Apoptotic } \\
{[\%]}\end{array}$ & $\begin{array}{c}8.46 \pm \\
{[\%}\end{array}$ & $\begin{array}{c}48.38 \pm \\
12.27\end{array}$ & $\begin{array}{c}56.47 \pm \\
6.39\end{array}$ & $\begin{array}{c}80.93 \pm \\
2.30\end{array}$ & $\begin{array}{c}28.34 \pm \\
11.41\end{array}$ & $\begin{array}{c}17.50 \pm \\
9.55\end{array}$ & $\begin{array}{c}45.09 \pm \\
11.05\end{array}$ & $\begin{array}{c}46.67 \pm \\
6.18\end{array}$ & $\begin{array}{c}61.47 \pm \\
0.95\end{array}$ & $\begin{array}{c}62.08 \pm \\
2.02\end{array}$ & $\begin{array}{c}90.41 \pm \\
4.44\end{array}$ \\
\hline
\end{tabular}

C

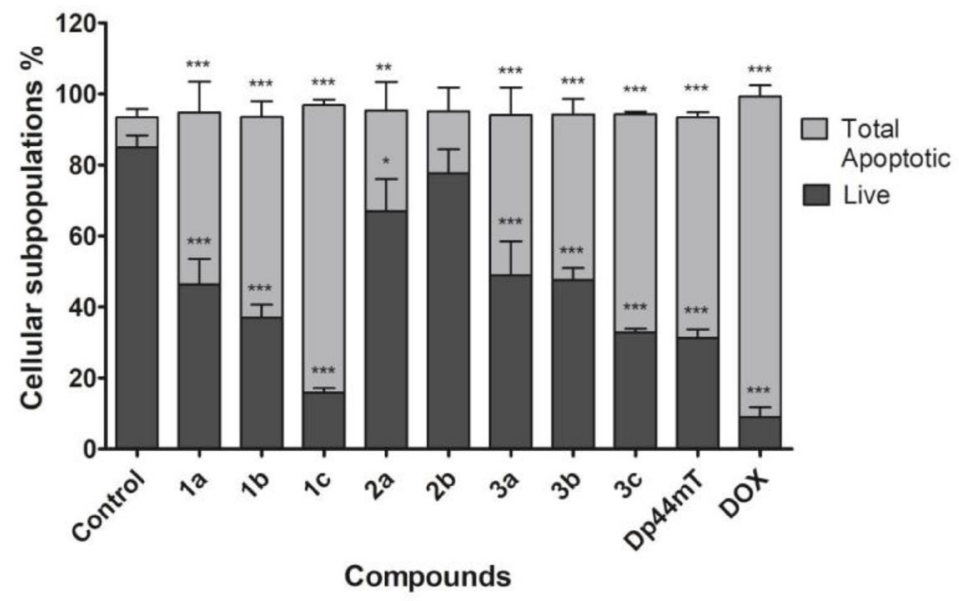

Figure 8: Evaluation of apoptosis induction in HCT116 cells after $48 \mathrm{~h}$ of treatment with TSC (1 $\mu \mathrm{M})$ and DOX (5 $\mu \mathrm{M})$. The histograms show the percentage of early and late apoptosis for one of experiments $(\mathbf{A})$. The table shows the mean \pm SD percentage of live, early and late apoptotic cells from three independent experiments (B). Data were analyzed using one-way ANOVA with Bonferroni's post-hoc test: ${ }^{*} p<0.05,{ }^{* *} p<0.01,{ }^{* * *} p<0.001$ compared to the control $(\mathbf{C})$. 
to increase oxidative processes or displacing other metals from their complexes with specific proteins. The redoxactive complexes of Dp44mT with lysosomes specific accumulation were reported by Lovejoy et al. [40]. Both of the structural fragments (quinoline/di-pyridine and thiosemicarbazone moieties) that are exploited in those new TSC are known to chelate metal ions. Considering this, we decided to investigate the mechanisms of oxidative stress induction after treatment with those highly potent TSC more deeply.

Our recent studies confirmed that TSC derivatives may be accumulated also in mitochondria [37]. This suggests that the ROS that were generated by the TSC may influence the antioxidant capacity and contribute to the disruption of mitochondria, which then triggers apoptosis. To evaluate this hypothesis, we measured the intracellular level of ROS and glutathione in time dependence manner. Results shown reverse dependence of changing ROS and GSH level. In general, ROS concentration increased along incubation time, reaching the maximum after $12 \mathrm{~h}$. The opposite effect was observed for GSH. Its level decreased during the whole experiment lasting $24 \mathrm{~h}$. GSH depletion is a strategy to overcome MDR-resistance and it is also an early event in cell death in response to different stimuli [12]. This, however, may occur in two different ways depending on the contribution of p53 [63, 64].
$1 a$

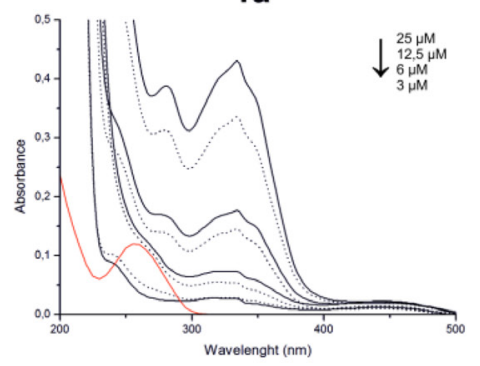

2a

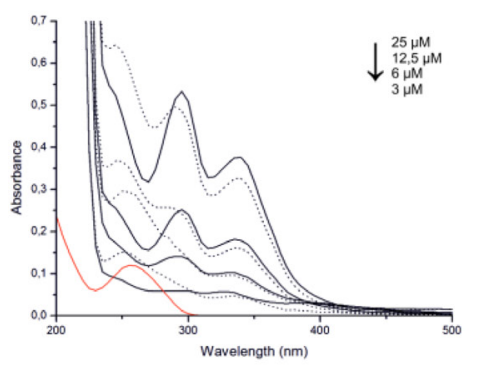

3b

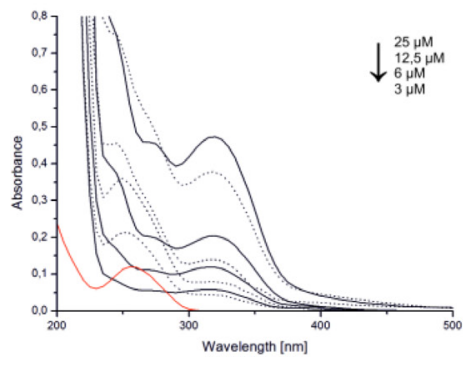

1b

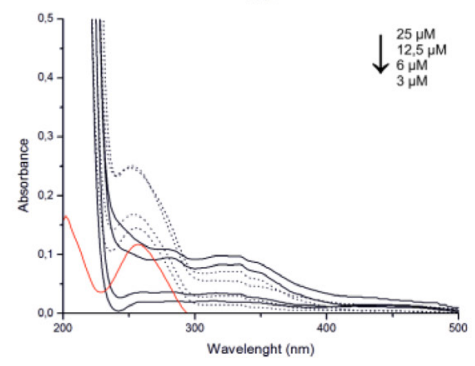

$2 \mathbf{b}$

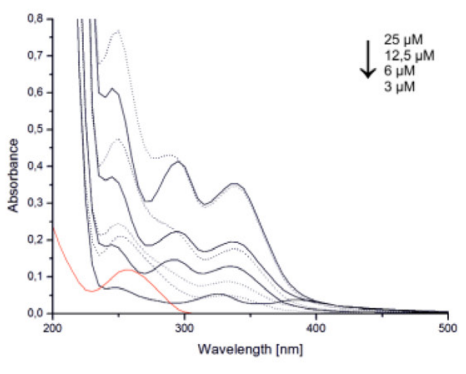

3c
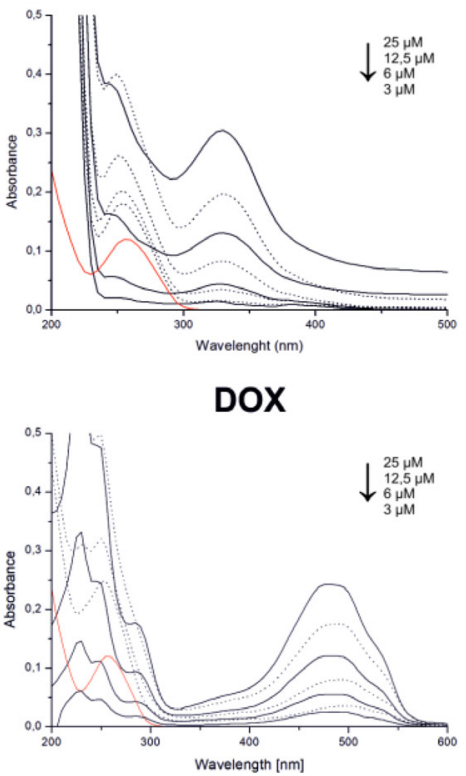

1c

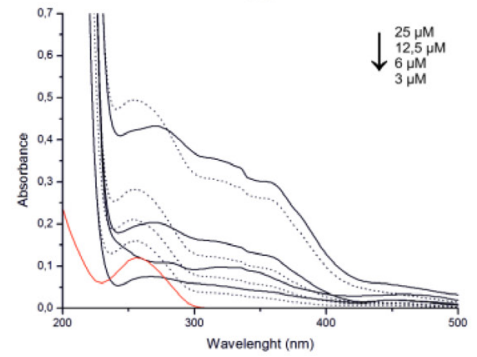

$3 a$

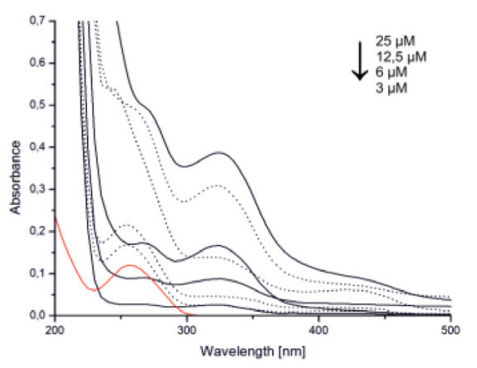

Dp44mT

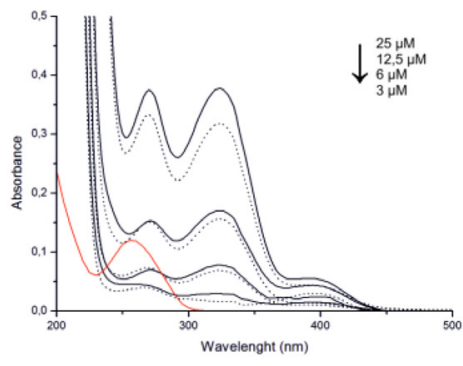

Figure 9: Absorption spectra of the tested thiosemicarbazones and DOX in the absence of CT-DNA (solid line) and in the presence of the CT-DNA (dotted line) in phosphate-buffered saline. Red line indicates the CT-DNA alone in PBS. 
Table 2: Absorption spectral properties of the tested compounds bound to CT-DNA

\begin{tabular}{|c|c|c|c|c|c|}
\hline Compound & $\begin{array}{c}\text { Absorption } \lambda_{\text {max }} \\
{[\mathrm{nm}]}\end{array}$ & $\begin{array}{l}\text { Changes in } \\
\text { absorbance }\end{array}$ & \% hypochromism & $\Delta \varepsilon \mathrm{M}^{-1} \mathrm{~cm}^{-1}$ & blue/red shift" [nm] \\
\hline $1 \mathrm{a}$ & $282 ; 334$ & hypochromism & 22.0 & 3175.6 & 1 \\
\hline $1 b$ & 324 & hypochromism & 24.2 & 2313.3 & 10 \\
\hline $1 \mathrm{c}$ & $272 ; 310$ & hypochromism & 22.6 & 2695.6 & 4 \\
\hline $2 \mathrm{a}$ & $295 ; 330$ & hypochromism & 15.7 & 1935.6 & 10 \\
\hline $2 b$ & $295 ; 338$ & hypochromism & 9.4 & 1888.9 & 5 \\
\hline $3 \mathrm{a}$ & 325 & hypochromism & 28.2 & 4120.0 & 5 \\
\hline $3 b$ & 320 & hypochromism & 31.9 & 6133.3 & 5 \\
\hline $3 \mathrm{c}$ & 330 & hypochromism & 28.5 & 3220.0 & 2 \\
\hline Dp44mT & $272 ; 324$ & hypochromism & 8.2 & 1673.3 & 2 \\
\hline $\mathrm{DOX}^{\mathrm{a}}$ & 480 & hypochromism & 34.2 & 3235.6 & 10 \\
\hline
\end{tabular}

*for the wavelengths of the maximum absorption for compounds alone and the DNA-bound compounds. ${ }^{\text {adata }}$ from [49].

For $3 \mathrm{a}$ we detected the highest ROS level (12 h), among all of the tested compounds. This can be correlated with anticancer activity and confirmed hypothesis, that mechanism of action is connected with ROS generation. Therefore the next step was to measure the expression of genes responsible for maintaining oxidative balance in cell. Genes expression dynamic correlates with the antiproliferative activity of the tested compounds. Such a reduction in antioxidant proteins following ROSinduced damage is a known trigger of apoptosis [65]. The inhibition of manganese superoxide dismutase and catalase expression appears to play a crucial role in breaking down the cellular defense against increased ROS level. Additionally catalase may affect the mechanism of multidrug resistance and protect tumor cells against the induction of apoptosis $[66,67]$. Ndrg1 expression is another important factor in the stress response that was observed to be considerably elevated. This gene is downregulated in various cancers, which is often connected with p53 level [68]. Amplification of this gene is frequently reported in response to chemotherapy and leads to the inhibition of growth and metastasis. Alterations of the intracellular level of iron through chelation and facilitated mobility have been identified as one of the triggers of Ndrg1 up-regulation [22].

With this in mind, we determined the influence of the tested TSC on the expression of p53 and p21 proteins, which are involved in cell cycle progression and apoptosis induction. Interestingly, none of the tested TSC induced the expression of the p53 protein. On the other hand, western blot analysis revealed a considerable up-regulation of the $\mathrm{p} 21$ protein after treatment with all of the compounds that were tested. The strongest effect, comparable to DOX, among the TSC was observed for 1c, $3 \mathrm{c}$ and Dp44mT. Those results indicate a p53-independent pathway of apoptosis. The Ndrg1 gene has also been reported to up-regulate $\mathrm{p} 21$ and activate WAF1/CIP1 expression as apoptotic triggers [69-71].

Cellular ROS level is strictly related to the cell cycle. In general a concentration of oxygen radical is steadily growing from $\mathrm{G} 1$ through $\mathrm{S}$ phase to $\mathrm{G} 2+\mathrm{M}$ and then drops back in quiescent state. Both antioxidant factors and prooxidant proteins are respectively changing, regulated by overall metabolism rate $[72,73]$. For example MnSOD level is repeatedly changing from high in G1 and $\mathrm{S}$ phases to low in $\mathrm{G} 2 / \mathrm{M}$. The same was observed for its conformation and electrostatic potential [74]. To fulfill the increased demand for energy, cells in the G0/G1 phase increase the activity of proteins such as MnSOD, which are responsible for redox homeostasis. As was suggested by Sarsour et al., eustress and oxidative stress are both crucial factors in cell cycle progression [72]. In response to oxidative damage or radiation stress MnSOD may be regulated through phosphorylation by cdc2 [75, 76]. Interestingly compounds $1 \mathrm{~b}, 3 \mathrm{~b}$ and $3 \mathrm{c}$ with strongest decreasing effect on cdc2 (Figure 6) caused also a large drop in the MnSOD level after $24 \mathrm{~h}$ of incubation (Figure 5). On the other hand however $2 \mathrm{~b}$ and $3 \mathrm{a}$ increased the expression of cdc2. The cdc2 protein is involved in the transition from the $\mathrm{G} 2$ to $\mathrm{M}$ phase and its activity is sustained from the prophase to the metaphase during mitosis. Moreover, for $2 \mathrm{~b}$ and $3 \mathrm{a}$ a relatively smaller increase in $\mathrm{S}$ phase and the highest increase in G2/M may be observed. Therefore, our results confirm cell cycle arrest in the $\mathrm{S}$ or $\mathrm{G} 2$ phase and the initiation of a mitotic catastrophe in HCT116 cells [77, 78]. On the other hand, Topham et al. postulated that the prolonged arrest of cells in the mitotic phase leads to their death via apoptosis, which is associated with the mitochondria signaling pathway [79].

Another possible mechanism of action, which characterizes most planar aromatic compounds, is 
intercalation of DNA. This can also be associated with interactions with transition metals such as iron, copper and nickel, which can form complexes with quinolines, 8-hydroxyquinolines and thiosemicarbazone derivatives [80-83]. Additionally, in previous studies, we indicated that the antiproliferative activity of quinoline-related compounds may be associated with the ability to intercalate into DNA, leading to the p53-independent mechanism of action of these compounds [49, 84]. Moreover, many iron chelators have been reported to be topoisomerase inhibitors or poisons [85]. The ability of ligands or metal complexes to bind to DNA may induce conformation changes, which as a result leads to DNA strand stress and damage [86]. In general interactions ligand-DNA may induce hypo- or hyperchromism. First is attributed with interaction of electronic state of compounds and those of DNA bases, increasing tightness of complex and $\pi$-stacking. The second effect, may reflect electrostatic binding (groove binders) or partial uncoiling of helix, as single stranded DNA revealed much stronger absorption as double helix. Strong hypochromism combined with redor blue-shift is regarded as typical sign of intercalation. The stronger the effect and wavelength shift associated, the stronger interaction is. Our results shown in general high intercalating potency of TSC that were tested. An exception is control compound Dp44mT, for which only small effect was observed. This simple, dimethylsubstituted molecule is known for weak interactions with CT-DNA [48]. Thus our results indicate the importance of both of the substructures that are connected with the thiosemicarbazone moiety. Di-pyridine or quinoline rings and large aromatic rings instead of dimethylamine (compare 3a-c and Dp44mT), particularly the piperazine ring, may interact with minor groove DNA and thereby improve intercalation [87]. For this series of TSC strongest hypochromism and strong red- or blue-shift was observed. For substituted pyridine $3 \mathrm{~b}$ the strongest hypopchromic effect was observed comparable with this of doxorubicin. On the other hand, series 2 of the thiosemicarbazones with the 8-hydroxyquinoline moiety had moderate intercalating properties. The combination of DNA intercalation and redox-active complexes may be responsible for the small amount of damage in the structure of the nucleic acids, which leads to cell cycle arrest as was indicated above. This hypothesis may explain the conflicting literature data suggesting that TSC do [88] or do not [89] interact directly with topoisomerases. This also corresponds with the fact that even non-intercalating TSC may induce some DNA damage via $\mathrm{Cu}$-complexes [90].

To sum up the ionophoric nature of these chelators and a high activity in the Haber-Weiss and Fenton reactions are responsible for their complex interactions with the cellular antioxidant system. The aromatic structure and chelation ability of novel TSC is a prerequisite for DNA intercalation. Increasing the ROS levels beyond the restoration capacity of a cell affects the regulation of the
MnSOD and CAT genes. This in turn up-regulates the Ndrg1 gene and leads to apoptosis. Despite the strong connection between iron metabolism and p53, all of the tested compounds triggered cell death in a p53-independent manner. These findings will hopefully help to understand and clarify the reports that are often contradictory.

\section{MATERIALS AND METHODS}

\section{Synthesis}

General reagents were purchased from Sigma-Aldrich (St. Louis, MO, USA) or ACROS Organics (Belgium). Thin layer chromatography (TLC) was performed on alumina-backed silica gel 40 F254 plates (Merck) and illuminated under UV (254 nm) The melting points were determined on Optimelt MPA100 instrument (SRS, USA) and are uncorrected. Syntheses were performed on a CEMDISCOVERY microwave reactor (CEM Corporation, Matthews, NC, USA) with temperature and pressure control. High resolution mass spectrometry (HRMS) analysis was performed for all new compounds on SYNAPT G2-S HDMS (Waters, USA). The purity of all compounds was assessed using a Agilent 1260 equipped with a DAAD detector at $260 \mathrm{~nm}$, RP-column: Eclipse plus C18 (3,5 $\mu \mathrm{m})$; flow $0.5 \mathrm{ml} / \mathrm{min}$. The time of each measurement was 21 min. Conditions: $0-0.8 \min \left(80 \% \mathrm{H}_{2} \mathrm{O}(0.1 \%\right.$ TFA $) ; 20 \%$ acetonitrile); $0.8-7 \min (100 \%$ acetonitrile); $7-13 \min (80 \%$ $\mathrm{H}_{2} \mathrm{O}(0.1 \%$ TFA); $20 \%$ acetonitrile).

All ${ }^{1} \mathrm{H}$ NMR spectra were recorded on a Bruker AM-400 spectrometer (400 MHz) as well as Bruker AVANCE III (500 MHz). Chemical shifts are reported in ppm against the internal standard, $\mathrm{Si}\left(\mathrm{CH}_{3}\right)_{4}$. Easily exchangeable signals were omitted when diffuse. In general, thiosemicarbazones - 1a, 2a-b, 3a-c, Dp44mT and their thiosemicarbazide precursors were synthesized and characterized, as described previously [35, 36]. Doxorubicin was purchased from Sigma-Aldrich.

\section{General procedure for the synthesis of thiosemicarbazones 1b-1c}

The mixtures of (1,1'-thiocarbonyl) bis- $1 H$ imidazole (5 mmol) and 4-(4-fluorophenyl)piperazine (5 mmol) or 4-[3-chloro-5-(trifluoromethyl)pyridin2-yl]piperazine $(5 \mathrm{mmol})$ in methylene chloride (25 $\mathrm{mL}$ ) were stirred for $24 \mathrm{~h}$ at room temperature. The solutions were extracted three times with distilled water and the organic phases were dried over $\mathrm{MgSO}_{4}$ and evaporated. The obtained thioketones were refluxed for 2 hours with hydrazine hydrate $(5 \mathrm{mmol})$. Finally, crude thiosemicarbazides were crystallized from dry methanol to obtain pure crystals. NMR spectra and mass spectrometry analysis is provided in Supplementary Figures 1-8.

4-(4-fluorophenyl)piperazine-1-carbothiohydrazide Light pink powder; yield 97\%; mp:180-181 ${ }^{\circ} \mathrm{C}$; ${ }^{1} \mathrm{H}-\mathrm{NMR}$ 
(400 MHz, $d_{6}$-DMSO, ppm): $\delta 3.09\left(\mathrm{~m}, 4 \mathrm{H}, \mathrm{CH}_{2}\right), 3.87$ $\left(\mathrm{m}, 4 \mathrm{H}, \mathrm{CH}_{2}\right), 4.77\left(\mathrm{~s}, 2 \mathrm{H}, \mathrm{NH}_{2}\right), 6.97(\mathrm{~m}, 2 \mathrm{H}, \mathrm{CH}), 7.05$ $(\mathrm{m}, 2 \mathrm{H}, \mathrm{CH}), 9.19(\mathrm{~s}, 1 \mathrm{H}, \mathrm{NH}) .{ }^{13} \mathrm{C}-\mathrm{NMR}\left(101 \mathrm{MHz}, d_{6}\right.$ DMSO, ppm): $\delta 40.3 ; 49.1 ; 115.9 ; 117.9 ; 148.0 ; 157.8$; 183.0.

4-[3-chloro-5-(trifluoromethyl)pyridin-2-yl]

piperazine-1-carbothiohydrazide White powder; yield 85\%; mp:191-192 ${ }^{\circ} \mathrm{C}$; ${ }^{1} \mathrm{H}-\mathrm{NMR}\left(500 \mathrm{MHz}, d_{6}\right.$-DMSO, ppm): $\delta 3.51\left(\mathrm{~m}, 4 \mathrm{H}, \mathrm{CH}_{2}\right), 3.88\left(\mathrm{~m}, 4 \mathrm{H}, \mathrm{CH}_{2}\right), 4.83(\mathrm{~s}$, $\left.2 \mathrm{H}, \mathrm{NH}_{2}\right), 8.20(\mathrm{~d}, 1 \mathrm{H} ; J=2.1 \mathrm{~Hz}), 8.56(\mathrm{~s}, 1 \mathrm{H}, \mathrm{CH})$, $9.18(\mathrm{~s}, 1 \mathrm{H}, \mathrm{NH}) .{ }^{13} \mathrm{C}-\mathrm{NMR}\left(126 \mathrm{MHz}, d_{6}\right.$-DMSO, ppm): $\delta 47.3 ; 48.1 ; 120.2 ; 122.8 ; 125.0 ; 136.8 ; 143.5 ; 159.7$; 183.2 .

\section{Microwave-assisted synthesis of thiosemicarbazones}

Two drops of glacial acetic acid were added as a catalyst to the mixtures of thiosemicarbazides $(0.5 \mathrm{mmol})$ and appropriate quinolinecarboxaldehyde $(0.5 \mathrm{mmol})$ in ethanol $(5 \mathrm{~mL})$. The glass tubes were sealed and placed into a microwave reactor at $83^{\circ} \mathrm{C}$ for 20 minutes (the reactor power did not exceed $50 \mathrm{~W}$ ). The final products were crystallized from methanol.

4-(4-fluorophenyl)-N'-[(quinolin-2-yl)methylidene] piperazine-1-carbothiohydrazide (1b) Yellow powder; yield 62\%; mp:192-193 ${ }^{\circ} \mathrm{C}$; ${ }^{1} \mathrm{H}-\mathrm{NMR}\left(500 \mathrm{MHz}, d_{6}\right.$ DMSO, ppm): $\delta 3.26\left(\mathrm{~m}, 4 \mathrm{H}, \mathrm{CH}_{2}\right) ; 4.13\left(\mathrm{~m}, 4 \mathrm{H}, \mathrm{CH}_{2}\right)$; $7.02(\mathrm{~m}, 2 \mathrm{H}, \mathrm{Ar}-\mathrm{H}) ; 7.09$ (t, 2H, $J=8.9 \mathrm{~Hz}) ; 7.63(\mathrm{~m}$, 1H, Ar-H); 7.78 (m, 1H, Ar-H); 7.99 (m, 1H, Ar-H); 8.03 $(\mathrm{m}, 2 \mathrm{H}, \mathrm{Ar}-\mathrm{H}) ; 8.35$ (s, 1H, CH); 8.39 (d, 1H, $J=8.7$ $\mathrm{Hz}) ; 11.67$ (s, 1H, NH). ${ }^{13} \mathrm{C}-\mathrm{NMR}\left(126 \mathrm{MHz}, d_{6}-\mathrm{DMSO}\right.$, ppm): $\delta 49.4 ; 50.4 ; 115.8 ; 115.9 ; 117.8 ; 127.6 ; 128.2$; $128.5 ; 129.3 ; 130.5 ; 137.2 ; 144.4 ; 147.9 ; 154.3 ; 155.8$; 157.6; 181.2. HRMS-ESI: calcd for $\mathrm{C}_{22} \mathrm{H}_{21} \mathrm{FN}_{4} \mathrm{~S} 394.1502$ $[\mathrm{M}+\mathrm{H}]^{+}$found 394.1494 .

4-[3-chloro-5-(trifluoromethyl)pyridin-2-yl]- $N$ '[quinolin-2-yl)methylidene]piperazine-1-carbothiohydrazide (1c) Yellow powder; yield 98\%; mp: $126-127^{\circ} \mathrm{C}$; ${ }^{1} \mathrm{H}-\mathrm{NMR}$ $\left(500 \mathrm{MHz}, d_{6}\right.$-DMSO, ppm): $\delta 3.69\left(\mathrm{~m}, 4 \mathrm{H}, \mathrm{CH}_{2}\right) ; 4.14$ (m, 4H, $\left.\mathrm{CH}_{2}\right) ; 7.62$ (m, 1H, Ar-H); 7.79 (m, 1H, Ar-H); 8.01 (m, 3H, Ar-H); 8.23 (d, 1H, $J=2.2 \mathrm{~Hz}) ; 8.34$ (s, 1H, $\mathrm{CH}) ; 8.38(\mathrm{~d}, 1 \mathrm{H}, J=8.7 \mathrm{~Hz}) ; 8.59(\mathrm{dd}, 1 \mathrm{H}, J=2.1,0.9$ $\mathrm{Hz}) ; 11.68$ (s, $1 \mathrm{H}, \mathrm{NH}) .{ }^{13} \mathrm{C}-\mathrm{NMR}\left(126 \mathrm{MHz}, d_{6}-\mathrm{DMSO}\right.$, ppm): $\delta 19.0 ; 48.3 ; 50.2 ; 56.5 ; 117.8 ; 120.0 ; 127.6 ; 128.2$; $128.5 ; 129.3 ; 130.5 ; 136.9 ; 137.1 ; 143.5 ; 144.4 ; 147.9$; $154.3 ; 159.6 ; 181.6$. HRMS-ESI: calcd for $\mathrm{C}_{22} \mathrm{H}_{19} \mathrm{ClF}_{3} \mathrm{~N}_{5} \mathrm{~S}$ $479.1033[\mathrm{M}+\mathrm{H}]^{+}$found 479.1025 .

\section{Cell culture}

The human colon cancer cell line HCT116 wild type and human breast carcinoma cell line MCF-7 were obtained from ATCC and the normal human fibroblast cell lines NHDF were obtained from PromoCell. Cells were grown as monolayer cultures in Dulbecco's modified Eagle's medium with an antibiotic gentamicin (200 $\mu \mathrm{L} / 100 \mathrm{~mL}$ medium) in $75 \mathrm{~cm}^{2}$ flasks (Nunc). DMEM for HCT116 and MCF-7 were supplemented with 12\% heatinactivated fetal bovine serum (Sigma) and for NHDF with $15 \%$ non-inactivated fetal bovine serum (Sigma). Cells were cultured under standard conditions at $37^{\circ} \mathrm{C}$ in a humidified atmosphere at $5 \% \mathrm{CO}_{2}$.

\section{Cytotoxicity studies}

The cells were seeded in 96-well plates (Nunc) at a density of 3,500 cells/well (HCT116 and MCF-7) and 3,000 cells/well (NHDF) and incubated at $37^{\circ} \mathrm{C}$ for $24 \mathrm{~h}$. The assay was performed following a $96 \mathrm{~h}$ incubation with varying concentrations of the compounds that were being tested. Then, $20 \mu \mathrm{L}$ of CellTiter $96^{\circledR} \mathrm{AQ}_{\text {ueous }}$ One SolutionMTS (Promega) was added to each well (with $100 \mu \mathrm{L}$ DMEM without phenol red) and incubated for $1 \mathrm{~h}$ at $37^{\circ}$ C. The optical densities of the samples were analyzed at $490 \mathrm{~nm}$ using a multi-plate reader (Synergy 4, Bio Tek). Results were expressed as a percentage of the control and calculated as the inhibitory concentration $\left(\mathrm{IC}_{50}\right)$ values (using GraphPad Prism 5). The $\mathrm{IC}_{50}$ parameter was defined as the compound concentration that was necessary to reduce the proliferation of cells to $50 \%$ of the untreated control. Each individual compound was tested in triplicate in a single experiment with each experiment being repeated three or four times.

\section{Impact of metal ions on cellular proliferation}

The HCT116 and MCF-7 cells were seeded in 96-well plates (Nunc) at a density of 3,500 cells/well and incubated at $37^{\circ} \mathrm{C}$ for $24 \mathrm{~h}$. The MTS assay was performed following a $96 \mathrm{~h}$ incubation with varying concentrations of the tested compounds. Additionally, a $20 \mu \mathrm{M}$ solution of $\mathrm{CuSO}_{4}, \mathrm{FeSO}_{4}$ or $\mathrm{FeCl}_{3}$ was added into wells with the tested compounds. The results were expressed as a percentage of the control and calculated as the inhibitory concentration $\left(\mathrm{IC}_{50}\right)$ values using GraphPad Prism 5. Each individual compound was tested in triplicate in a single experiment with each experiment being repeated three times.

\section{Reactive oxygen species formation - microscope images}

The HCT116 cells were seeded into eight-well chambers (Lab-Tek) at a density of $0.5 \times 10^{5}$ cells/well and incubated at $37^{\circ} \mathrm{C}$. After $24 \mathrm{~h}$, freshly prepared solutions of the tested compounds: 1b, 1c, 2a-b, 3a-c and DOX (twofold $\mathrm{IC}_{50}$ concentration) were added. The next day, the solutions of the tested compounds were removed and the cells were washed with Phosphate Buffered Saline (PBS), after which $5 \mu \mathrm{M}$ CellROX ${ }^{\circledR}$ Green Reagent (Molecular Probes $^{\mathrm{TM}}$ ) was added. After $30 \mathrm{~min}$ of incubation at $37^{\circ} \mathrm{C}$, the cells were washed with PBS and then DMEM without 
phenol red was added. The observation was performed using an inverted fluorescence microscope (IX81, Olympus) equipped with a $\mathrm{CO}_{2}$ incubator using a $485 \mathrm{~nm}$ excitation laser and a $520 \mathrm{~nm}$ emission filter.

\section{Time dependent measurement of ROS level}

To determine the intracellular levels of ROS, HCT116 cells were seeded onto black 96-well plates (Corning) at a density of 9,000 cells/well and incubated at $37^{\circ} \mathrm{C}$. After an overnight incubation, the solutions of the tested compounds: 1a-c, 2 a-b, 3 a-c, Dp44mT (1 $\mu \mathrm{M})$ and $\operatorname{DOX}(5 \mu \mathrm{M})$ were added and incubated for $3,6,9,12$, and $24 \mathrm{~h}$ in a kinetic experiment. The generation of ROS was measured using a CellROX ${ }^{\circledR}$ Green Reagent (Molecular Probes $\left.^{\mathrm{TM}}\right)$. Additionally, the quantity of cells in each well was determined using Hoechst 33342 (Molecular Probes $^{\mathrm{TM}}$ ). The solutions of the tested compounds were removed and $100 \mu \mathrm{L}$ of CellROX Green Reagent and Hoechst 33342 at a final concentration of $5 \mu \mathrm{M}$ were added to each well. Then, the cells were incubated for $30 \mathrm{~min}$ at $37^{\circ} \mathrm{C}$. The fluorescence was measured using a multi-plate reader (Synergy 4, Bio Tek) at $485 \mathrm{~nm}$ excitation and a $520 \mathrm{~nm}$ emission for CellROX Green Reagent and a $345 \mathrm{~nm}$ excitation laser and a $485 \mathrm{~nm}$ emission filter for Hoechst 33342. The experiments were performed three to four times. ROS levels were expressed as the percentage of the control cells level.

\section{Time dependent measurement of glutathione level}

To determine the intracellular level of reduced glutathione, the HCT116 cells were seeded in $3 \mathrm{~cm}$ Petri dishes (Nunc) at a density of $0.5 \times 10^{6}$ cells/well and incubated at $37^{\circ} \mathrm{C}$. The next day, solutions of TSC $(1 \mu \mathrm{M})$ and $\operatorname{DOX}(5 \mu \mathrm{M})$ were added and incubated for $3,6,9,12$, and $24 \mathrm{~h}$ in a kinetic experiment. The levels of intracellular GSH were measured using an enzymatic recycling method [91]. Briefly, $20 \mu \mathrm{L}$ of each cell lysate was transferred into 96-well plates. Then, freshly prepared solutions of 5,5'-dithio-bis(2-nitrobenzoic acid) (DNTB) at a final concentration of $0.67 \mathrm{mg} / \mathrm{mL}$ and glutathione reductase (GR) - 1.67 units $/ \mathrm{mL}$, were added to each well. After 30 sec, $\beta$-NADPH $(0.67 \mathrm{mg} / \mathrm{mL})$ was added to each well and the absorbance was immediately measured at $412 \mathrm{~nm}$ in a multi-plate reader (Synergy 4, Bio Tek). The experiments were performed in triplicate. Data were expressed as the percentage of the control cells level.

\section{Analysis of the mRNA expression of MnSOD, CAT, Ndrg1}

The HCT116 cells were seeded in $3 \mathrm{~cm}$ Petri dishes (Nunc) at a density of $0.5 \cdot 10^{6}$ cells/well and incubated overnight. Next, the medium was removed and solutions of TSC $(1 \mu \mathrm{M})$ and DOX $(5 \mu \mathrm{M})$ were added. After 12 or $24 \mathrm{~h}$, total RNA was isolated from the cells using TRIzol Reagent (Ambion) according to the manufacturer's instructions. cDNA synthesis was performed with $5 \mu \mathrm{g}$ of total RNA using a GoScript ${ }^{\mathrm{TM}}$ Reverse Transcriptase kit (Promega) and Oligo(dT) ${ }_{23}$ Primers (Sigma). The Real-Time PCR was performed with a CTX96 Touch $^{\text {TM }}$ Real-Time PCR Detection System (Biorad) in a $20 \mu \mathrm{L}$ reaction volume. The reaction consisted of PowerUp ${ }^{\mathrm{TM}}$ SYBR $^{\circledR}$ Green Master Mix (Applied Biosystems), a primer pair mix $(0.5 \mu \mathrm{M}$ each) and $1 \mu \mathrm{L}$ of cDNA. All primer pair sequences were purchased from SigmaAldrich and are listed in Supplementary Table 2. The experiment was performed under the following conditions: initial denaturation at $95^{\circ} \mathrm{C}$ for $120 \mathrm{sec}$; followed by 40 denaturation cycles at $95^{\circ} \mathrm{C}, 15 \mathrm{sec}$; annealing (primerspecific temperature for $30 \mathrm{sec}$ ) and extension at $72^{\circ} \mathrm{C}$ for $60 \mathrm{sec}$. Data was analyzed based on a comparison of the expression of the target genes to a reference gene $\beta$-actin, using the $2^{-\triangle \Delta C \mathrm{CT}}$ method. The experiments were performed at least three times.

\section{Immunoblotting}

The HCT116 cells were seeded in $3 \mathrm{~cm}$ Petri dishes (Nunc) at a density of $0.5 \cdot 10^{6}$ cells/well and incubated overnight. The next day, solutions of TSC $(1 \mu \mathrm{M})$ and $\operatorname{DOX}(5 \mu \mathrm{M})$ were added and the cells incubated for 24 or $48 \mathrm{~h}$. Cells were harvested by trypsinization and washed with cold PBS. Next, the cells were centrifuged and suspended in an RIPA buffer (Thermo Scientific) containing Halt Protease Inhibitor Cocktail (Thermo Scientific), Halt Phosphatase Inhibitor Cocktail (Thermo Scientific) along with $0.5 \mathrm{M}$ EDTA and lysed for $20 \mathrm{~min}$ on ice. Then, the lysates were sonicated, centrifuged at $10,000 \mathrm{rpm}$ for 10 $\min$ at $4^{\circ} \mathrm{C}$ and the supernatants were collected for further analysis. The protein concentration was determined using a Micro BCA $^{\mathrm{TM}}$ Protein Assay Kit (Thermo Scientific) according to the manufacturer's instructions. Equal amounts of the proteins $(20 \mu \mathrm{g})$ were electrophoresed on SDS-Page gels and transferred onto a nitrocellulose membranes. The membranes were blocked in 5\% non-fat milk prepared in PBS containing 0.1\% Tween-20 (TPBS) for $1 \mathrm{~h}$. After blocking, the membranes were incubated with specific primary antibodies: cdc2 (\#POH1, Cell Signaling), p21 Waf1/Cip1 (\#12D1, Cell Signaling), p53 (\#1C12, Cell Signaling) and $\beta$-Actin (\#8H10D10, Cell Signaling) overnight at $4^{\circ} \mathrm{C}$, then washed and incubated with horseradish peroxidase (HRP)-conjugated secondary antibodies for $1 \mathrm{~h}$ at room temperature. All of antibodies were diluted 1:1000 in 5\% milk in TPBS. Finally, the membranes were washed and incubated with a SuperSignal ${ }^{\mathrm{TM}}$ West Pico Chemiluminescent Substrate (Thermo Scientific). The chemiluminescence signals were captured using a ChemiDoc $^{\mathrm{TM}}$ XRS + System (BioRad). The experiments were performed at least three times. Densitometric analysis 
was performed using ImageJ 1.41 software (Wayne Rasband, National Institutes of Health, USA).

\section{Cell cycle assay}

The HCT116 cells were seeded in $3 \mathrm{~cm}$ Petri dishes (Nunc) at a density of $0.25 \cdot 10^{6}$ cells/well and incubated at $37^{\circ} \mathrm{C}$ for $24 \mathrm{~h}$. Then, the medium was removed and freshly prepared solutions of the tested TSC $(0.5 \mu \mathrm{M})$ and DOX $(5 \mu \mathrm{M})$ were added. After a $48 \mathrm{~h}$ treatment, assays were performed using a Muse Cell-Cycle Kit (Millipore) according to the manufacturer's instructions. Briefly, cells were collected, washed with cold PBS and centrifuged at $300 \mathrm{~g}$. Then, the cells were fixed in ice cold $70 \%$ ethanol and stored at $-20^{\circ} \mathrm{C}$ overnight. Afterwards, the cells were centrifuged and resuspended in $200 \mu \mathrm{L}$ of Muse $^{\mathrm{TM}}$ Cell Cycle Reagent and incubated for $30 \mathrm{~min}$ at room temperature in the dark. After staining, the cells were processed for cell cycle analysis using a Muse Cell Analyzer (Millipore). The experiments were performed at least three times.

\section{Annexin V binding assay}

The HCT116 cells were seeded in $3 \mathrm{~cm}$ Petri dishes (Nunc) at a density of $0.25 \cdot 10^{6}$ cells/well and incubated at $37^{\circ} \mathrm{C}$ for $24 \mathrm{~h}$. Then, the medium was removed and freshly prepared solutions of the tested TSC $(0.5 \mu \mathrm{M})$ and DOX $(5 \mu \mathrm{M})$ were added. After $48 \mathrm{~h}$, assays were performed using an Annexin V \& Dead Cell Kit (Millipore) according to the manufacturer's instructions. Briefly, detached and adherent cells were collected and centrifuged at $500 \mathrm{~g}$ for $5 \mathrm{~min}$. Afterwards, the resuspended cells were incubated with $100 \mu \mathrm{L}$ of Muse ${ }^{\mathrm{TM}}$ Annexin V \& Dead Cell Reagent for $20 \mathrm{~min}$ at room temperature in the dark. After staining, the events for live, early and late apoptotic cells were counted using a Muse Cell Analyzer (Millipore). The experiments were performed at least three times.

\section{Intercalation}

For the DNA binding studies, Calf-thymus DNA (CTDNA) was purchased from Sigma Aldrich. The lyophilized CT-DNA was dissolved in $10 \mathrm{mM}$ Tris-HCl, $\mathrm{pH} 7.9$, mixed gently and left overnight at $4^{\circ} \mathrm{C}$. The purity of the CTDNA solution was determined by measuring the ratio of UV absorbance at 260 and $280 \mathrm{~nm}$. A ratio more than 1.8 indicated that the DNA was sufficiently free from proteins. Then, the concentration of CT-DNA was determined from the absorbance at $260 \mathrm{~nm}$ using an extinction coefficient of $6600 \mathrm{M}^{-1} \mathrm{~cm}^{-1}$. The tested TSC and DOX were dissolved in DMSO to a concentration of $8.35 \mathrm{mM}$, which was then used as the stock solution for preparing the various concentrations $(25,12.5,6$ and $3 \mu \mathrm{M})$ in $1 \mathrm{~mL}$ in $10 \mathrm{mM}$ of Tris- $\mathrm{HCl}$ (pH 7.9). Afterwards, $18 \mu \mathrm{M}$ CT-DNA was added to the prepared solutions, which were incubated for $1.5 \mathrm{~h}$ at $37^{\circ} \mathrm{C}$ with occasional vortexing. The absorption spectra were measured using a Hitachi U-2900 spectrophotometer in range of $200-500 \mathrm{~nm}$. All absorption spectra were imported and compared in OriginPro 8.0.

\section{Statistical analysis}

Results are expressed as the mean \pm standard deviation (SD) from at least three independent experiments. Statistical analysis in the ROS, GSH measurements and expression of genes were performed using the two-tailed Student's $t$-test. Statistical differences in the expression of proteins, progression of cell cycle and Annexin $\mathrm{V}$ binding assay were calculated using one-way ANOVA with a Bonferroni post-hoc test. A $p$-value of 0.05 or less was considered to be statistically significant. GraphPad Prism v.5.0 software (GraphPad Software, USA) was used for analysis.

\section{Abbreviations}

ATP: adenosine triphosphate; CAT: catalase; CTDNA: calf-thymus DNA; DOX: doxorubicin; GSH: glutathione; GSSG: oxidized glutathione; MDR: multi-drug resistance; MnSOD: manganese superoxide dismutase; Ndrg1: N-myc downstream regulated gene 1; PDT: photodynamic therapy; ROS: reactive oxygen species; RR: ribonucleotide reductase; TSC: thiosemicarbazones.

\section{Author contributions}

$\mathrm{KM}$ and $\mathrm{AMW}$ performed biological tests and prepared the manuscript; MR and MS carried out chemical syntheses; JP edited the text and RM, KM and AMW designed the experiments, RM wrote the manuscript.

\section{CONFLICTS OF INTEREST}

The authors declare no competing interest.

\section{FUNDING}

The financial support of the National Science Centre grants 2014/13/D/NZ7/00322 (A.M.W.), 2013/09/B/ NZ7/00423 (R.M.) is greatly appreciated.

\section{REFERENCES}

1. Gorrini C, Harris IS, Mak TW. Modulation of oxidative stress as an anticancer strategy. Nat Rev Drug Discov. 2013; 12:931-47.

2. Nogueira V, Hay N. Molecular Pathways: Reactive Oxygen Species Homeostasis in Cancer Cells and Implications for Cancer Therapy. Clin Cancer Res. 2013; 19:4309-14. 
3. Sreevalsan S, Safe S. Reactive oxygen species and colorectal cancer. Curr Colorectal Cancer Rep. 2013; 9:350-7.

4. Zhang L, Li J, Zong L, Chen X, Chen K, Jiang Z, Nan L, Li X, Li W, Shan T, Ma Q, Ma Z. Reactive Oxygen Species and Targeted Therapy for Pancreatic Cancer. Oxid Med Cell Longev. 2016; 2016: 1616781.

5. Polimeni M, Gazzano E. Is redox signaling a feasible target for overcoming multidrug resistance in cancer chemotherapy? Front Pharmacol. 2014; 5: 286.

6. Trachootham D, Alexandre J, Huang P. Targeting cancer cells by ROS-mediated mechanisms: a radical therapeutic approach? Nat Rev Drug Discov. 2009; 8:579-91.

7. Manda G, Nechifor MT, Neagu TM. Reactive Oxygen Species, Cancer and Anti-Cancer Therapies. Curr Chem Biol. 2009; 3:342-66.

8. Glasauer A, Chandel NS. Targeting antioxidants for cancer therapy. Biochem Pharmacol. 2014; 92:90-101.

9. Aquilano K, Baldelli S, Ciriolo MR. Glutathione: new roles in redox signaling for an old antioxidant. Front Pharmacol. 2014; 5: 196.

10. Circu ML, Aw TY. Reactive oxygen species, cellular redox systems, and apoptosis. Free Radic Biol Med. 2010; 48:749-62.

11. Franco R, Cidlowski JA. Glutathione efflux and cell death. Antioxid Redox Signal. 2012; 17:1694-713.

12. Traverso N, Ricciarelli R, Nitti M, Marengo B, Furfaro AL, Pronzato MA, Marinari UM, Domenicotti C. Role of glutathione in cancer progression and chemoresistance. Oxid Med Cell Longev. 2013; 2013: 972913.

13. Hileman EO, Liu J, Albitar M, Keating MJ, Huang P. Intrinsic oxidative stress in cancer cells: A biochemical basis for therapeutic selectivity. Cancer Chemother Pharmacol. 2004; 53:209-19.

14. Kalinowski DS, Stefani C, Toyokuni S, Ganz T, Anderson GJ, Subramaniam NV, Trinder D, Olynyk JK, Chua A, Jansson PJ, Sahni S, Lane DJ, Merlot AM, et al. Redox cycling metals: pedaling their roles in metabolism and their use in the development of $n$ ovel therapeutics. Biochim Biophys Acta. 2016; 1863:727-48.

15. Kalinowski D, Richardson D. The evolution of iron chelators for the treatment of iron overload disease and cancer. Pharmacol Rev. 2005; 57:547-83.

16. Denoyer D, Masaldan S, La Fontaine S, Cater MA. Targeting copper in cancer therapy: "Copper That Cancer". Metallomics. 2015; 7:1459-76.

17. Liou GY, Storz P. Reactive oxygen species in cancer. Free Radic Res. 2010; 44:479-96.

18. Bedford MR, Ford SJ, Horniblow RD, Iqbal TH, Tselepis C. Iron Chelation in the Treatment of Cancer: A New Role for Deferasirox? J Clin Pharmacol. 2013; 53:885-91.

19. Yu Y, Gutierrez E, Kovacevic Z, Saletta F, Obeidy P, Suryo Rahmanto Y, Richardson DR. Iron chelators for the treatment of cancer. Curr Med Chem. 2012; 19:2689-702.
20. Kalinowski DS, Yu Y, Sharpe PC, Islam M, Liao YT, Lovejoy DB, Kumar N, Bernhardt PV, Richardson DR. Design, synthesis, and characterization of novel iron chelators: structure-activity relationships of the 2-benzoylpyridine thiosemicarbazone series and their 3-nitrobenzoyl analogues as potent antitumor agents. J Med Chem. 2007; 50:3716-29.

21. Jansson PJ, Sharpe PC, Bernhardt PV, Richardson DR. Novel thiosemicarbazones of the ApT and DpT series and their copper complexes: identification of pronounced redox activity and characterization of their antitumor activity. $\mathrm{J}$ Med Chem. 2010; 53:5759-69.

22. Le NT, Richardson DR. Iron chelators with high antiproliferative activity up-regulate the expression of a growth inhibitory and metastasis suppressor gene: A link between iron metabolism and proliferation. Blood. 2004; 104:2967-75.

23. Richardson DR, Sharpe PC, Lovejoy DB, Senaratne D, Kalinowski DS, Islam M, Bernhardt PV. Dipyridyl thiosemicarbazone chelators with potent and selective antitumor activity form iron complexes with redox activity. J Med Chem. 2006; 49:6510-21.

24. Gutierrez EM, Seebacher NA, Arzuman L, Kovacevic Z, Lane DJR, Richardson V, Merlot AM, Lok H, Kalinowski DS, Sahni S, Jansson PJ, Richardson DR. Lysosomal membrane stability plays a major role in the cytotoxic activity of the anti-proliferative agent, di-2-pyridylketone 4,4-dimethyl-3-thiosemicarbazone (Dp44mT). Biochim Biophys Acta. 2016; 1863:1665-81.

25. Merlot AM, Kalinowski DS, Richardson DR. Novel chelators for cancer treatment: where are we now? Antioxid Redox Signal. 2013; 18:973-1006.

26. Jansson PJ, Yamagishi T, Arvind A, Seebacher N, Gutierrez E, Stacy A, Maleki S, Sharp D, Sahni S, Richardson DR. Di-2pyridylketone 4,4-Dimethyl-3-thiosemicarbazone (Dp44mT) Overcomes Multidrug-Resistance by a Novel Mechanism Involving the Hijacking of Lysosomal P-Glycoprotein (Pgp). J Biol Chem. 2015; 290:9588-603.

27. Stefani C, Punnia-Moorthy G, Lovejoy DB, Jansson PJ, Kalinowski DS, Sharpe PC, Bernhardt PV, Richardson DR. Halogenated 2'-benzoylpyridine thiosemicarbazone (XBpT) chelators with potent and selective anti-neoplastic activity: relationship to intracellular redox activity. J Med Chem. 2011; 54:6936-48.

28. Richardson DR, Kalinowski DS, Lau S, Jansson PJ, Lovejoy DB. Cancer cell iron metabolism and the development of potent iron chelators as anti-tumour agents. Biochim Biophys Acta. 2009; 1790:702-17.

29. Kovacevic Z, Chikhani S, Lovejoy DB, Richardson DR. Novel thiosemicarbazone iron chelators induce up-regulation and phosphorylation of the metastasis suppressor N-myc down-stream regulated gene 1: a new strategy for the treatment of pancreatic cancer. Mol Pharmacol. 2011; 80:598-609. 
30. Askautrud HA, Gjernes E, Gunnes G, Sletten M, Ross DT, Brøresen-Dale AL, Iversen N, Tranulis MA, Frengen E. Global gene expression analysis reveals a link between NDRG1 and vesicle transport. PLoS One. 2014; 9:e87268.

31. Mackenzie MJ, Saltman D, Hirte H, Low J, Johnson C, Pond G, Moore MJ. A Phase II study of 3-aminopyridine-2carboxaldehyde thiosemicarbazone (3-AP) and gemcitabine in advanced pancreatic carcinoma. A trial of the Princess Margaret hospital Phase II consortium. Invest New Drugs. 2007; 25:553-558.

32. Jansson PJ, Kalinowski DS, Lane DJR, Kovacevic Z, Seebacher NA, Fouani L, Sahni S, Merlot AM, Richardson DR. The renaissance of polypharmacology in the development of anti-cancer therapeutics: Inhibition of the "Triad of Death" in cancer by Di-2-pyridylketone thiosemicarbazones. Pharmacol Res. 2015; 100:255-60.

33. Whitnall M, Howard J, Ponka P, Richardson DR. A class of iron chelators with a wide spectrum of potent antitumor activity that overcomes resistance to chemotherapeutics. Proc Natl Acad Sci USA. 2006; 103:14901-06.

34. Serda M, Kalinowski DS, Mrozek-Wilczkiewicz A, Musiol R, Szurko A, Ratuszna A, Pantarat N, Kovacevic Z, Merlot AM, Richardson DR, Polanski J. Synthesis and characterization of quinoline-based thiosemicarbazones and correlation of cellular iron-binding efficacy to anti-tumor efficacy. Bioorg Med Chem Lett. 2012; 22:5527-31.

35. Serda M, Kalinowski DS, Rasko N, Potůčková E, MrozekWilczkiewicz A, Musiol R, Małecki JG, Sajewicz M, Ratuszna A, Muchowicz A, Gołąb J, Simůnek T, Richardson DR, Polanski J. Exploring the anti-cancer activity of novel thiosemicarbazones generated through the combination of retro-fragments: dissection of critical structure-activity relationships. PLoS One. 2014; 9:e110291.

36. Mrozek-Wilczkiewicz A, Serda M, Musiol R, Malecki G, Szurko A, Muchowicz A, Golab J, Ratuszna A, Polanski J. Iron Chelators in Photodynamic Therapy Revisited: Synergistic Effect by Novel Highly Active Thiosemicarbazones. ACS Med Chem Lett. 2014; 5:336-9.

37. Mrozek-Wilczkiewicz A, Malarz K, Rams-Baron M, Serda M, Bauer D, Montforts FP, Ratuszna A, Burley T, Polanski J, Musiol R. Iron Chelators and Exogenic Photosensitizers. Synergy through Oxidative Stress Gene Expression. J Cancer. 2017; 8:1979-87.

38. Akladios FN, Andrew SD, Parkinson CJ. Selective induction of oxidative stress in cancer cells via synergistic combinations of agents targeting redox homeostasis. Bioorg Med Chem. 2015; 23:3097-104.

39. Gao J, Richardson DR. The potential of iron chelators of the pyridoxal isonicotinoyl hydrazone class as effective antiproliferative agents, IV: The mechanisms involved in inhibiting cell-cycle progression. Blood. 2001; 98:842-50.

40. Lovejoy DB, Jansson PJ, Brunk UT, Wong J, Ponka P, Richardson DR. Antitumor activity of metal-chelating compound Dp44mT is mediated by formation of a redox-active copper complex that accumulates in lysosomes. Cancer Res. 2011; 71:5871-80.

41. Akladios FN, Andrew SD, Parkinson CJ. Improved cytotoxicity of pyridyl-substituted thiosemicarbazones against MCF-7 when used as metal ionophores. Biometals. 2016; 29:157-170.

42. Akladios FN, Andrew SD, Parkinson CJ. Investigation of the cytotoxic implications of metal chelators against melanoma and approaches to improve the cytotoxicity profiles of metal coordinating agents. Biometals. 2016; 29:789-805.

43. Kowol CR, Trondl R, Heffeter P, Arion VB, Jakupec MA, Roller A, Galanski M, Berger W, Keppler BK. Impact of metal coordination on cytotoxicity of 3-aminopyridine-2carboxaldehyde thiosemicarbazone (triapine) and novel insights into terminal dimethylation. J Med Chem. 2009; 52:5032-43. https://doi.org/10.1021/jm900528d.

44. Fouani L, Menezes SV, Paulson M, Richardson DR, Kovacevic Z. Metals and metastasis: Exploiting the role of metals in cancer metastasis to develop novel anti-metastatic agents. Pharmacol Res. 2017; 115:275-87.

45. Lane DJ, Saletta F, Rahmanto YS, Kovacevic Z, Richardson DR. Correction: n-myc Downstream Regulated 1 (NDRG1) is regulated by eukaryotic initiation factor $3 a$ (eIF3a) during cellular stress caused by iron depletion. PLoS One. 2016; 11:e0149922.

46. Barton JK, Danishefsky AT, Goldberg JM. Tris(phenanthroline)ruthenium(11): Stereoselectivity in Binding to DNA. J Am Chem Soc. 1984; 106:2172-6.

47. Airoldi M, Barone G, Gennaro G, Giuliani AM, Giustini M. Interaction of Doxorubicin with Polynucleotides. A Spectroscopic Study. Biochemistry. 2014; 53:2197-207.

48. Xu Z, Liu Y, Zhou S, Fu Y, Li C. Analysis of the Interaction of Dp44mT with Human Serum Albumin and Calf Thymus DNA Using Molecular Docking and Spectroscopic Techniques. Int J Mol Sci. 2016; 17: 1042.

49. Mrozek-Wilczkiewicz A, Spaczyńska E, Malarz K, Cieslik W, Rams-Baron M, Kryštof V, Musiol R. Design, synthesis and in vitro activity of anticancer styrylquinolines. The p53 independent mechanism of action. PLoS One. 2015; 10:e0142678.

50. Ding WQ, Lind SE. Metal ionophores - An emerging class of anticancer drugs. IUBMB Life. 2009; 61:1013-1018.

51. Moorthy NS, Cerqueira NM, Ramos MJ, Fernandes PA. Aryl- and heteroaryl-thiosemicarbazone derivatives and their metal complexes: a pharmacological template. Recent Patents Anticancer Drug Discov. 2013; 8:168-82.

52. Easmon J, Pürstinger G, Heinisch G, Roth T, Fiebig HH, Holzer W, Jäger W, Jenny M, Hofmann J. Synthesis, cytotoxicity, and antitumor activity of copper(II) and iron(II) complexes of 4N-azabicyclo[3.2.2]nonane Thiosemicarbazones derived from acyl diazines. J Med Chem. 2001; 44:2164-2171. 
53. Shao J, Zhou B, Di Bilio AJ, Zhu L, Wang T, Qi C, Shih J, Yen Y. A ferrous-Triapine complex mediates formation of reactive oxygen species chat inactivate human ribonucleotide reductase. Mol Cancer Ther. 2006; 5:586-592.

54. Haklar G, Sayin-Özveri E, Yüksel M, Aktan AÖ, Yalçin AS. Different kinds of reactive oxygen and nitrogen species were detected in colon and breast tumors. Cancer Lett. 2001; 165:219-224.

55. Jiang XP, Wang F, Yang DC, Elliott RL, Head JF. Induction of apoptosis by iron depletion in the human breast cancer MCF-7 cell line and the 13762NF rat mammary adenocarcinoma in vivo. Anticancer Res. 2002; 22:2685-2692.

56. Bolloskis MP, Carvalho FP, Loo G. Iron depletion in HCT116 cells diminishes the upregulatory effect of phenethyl isothiocyanate on heme oxygenase-1. Toxicol Appl Pharmacol. 2016; 297:22-31.

57. Torti SV, Torti FM. Iron and cancer: more ore to be mined. Nat Rev Cancer. 2013; 13:342-355.

58. Chekhun VF, Lukyanova NY, Burlaka CA, Bezdenezhnykh NA, Shpyleva SI, Tryndyak VP, Beland FA, Pogribny IP. Iron metabolism disturbances in the MCF-7 human breast cancer cells with acquired resistance to doxorubicin and cisplatin. Int J Oncol. 2013; 43:1481-6.

59. Lu JJ, Chen SM, Zhang XW, Ding J, Meng LH. The anticancer activity of dihydroartemisinin is associated with induction of iron-dependent endoplasmic reticulum stress in colorectal carcinoma HCT116 cells. Invest New Drugs. 2011; 29:1276-1283.

60. Finch RA, Liu MC, Grill SP, Rose WC, Loomis R, Vasquez KM, Cheng YC, Sartorelli AC. Triapine (3-aminopyridine2-carboxaldehyde- thiosemicarbazone): A potent inhibitor of ribonucleotide reductase activity with broad spectrum antitumor activity. Biochem Pharmacol. 2000; 59:983-991.

61. Chaston TB, Lovejoy DB, Watts RN, Richardson DR. Examination of the antiproliferative activity of iron chelators: Multiple cellular targets and the different mechanism of action of triapine compared with desferrioxamine and the potent pyridoxal isonicotinoyl hydrazone analogue 311. Clin Cancer Res. 2003; 9:402-414.

62. Gupte A, Mumper RJ. Elevated copper and oxidative stress in cancer cells as a target for cancer treatment. Cancer Treat Rev. 2009; 35:32-46.

63. Armstrong JS, Steinauer KK, Hornung B, Irish JM, Lecane P, Birrell GW, Peehl DM, Knox SJ. Role of glutathione depletion and reactive oxygen species generation in apoptotic signaling in a human B lymphoma cell line. Cell Death Differ. 2002; 9:252-263.

64. Hussain SP, Amstad P, He P, Robles A, Lupold S, Kaneko I, Ichimiya M, Sengupta S, Mechanic L, Okamura S, Hofseth LJ, Moake M, Nagashima M, et al. p53-Induced Up-Regulation of MnSOD and GPx but not Catalase
Increases Oxidative Stress and Apoptosis. Cancer Res. 2004; 64:2350-2356.

65. Valdameri G, Trombetta-Lima M, Worfel PR, Pires AR, Martinez GR, Noleto GR, Cadena SM, Sogayar MC, Winnischofe r SM, Rocha ME. Involvement of catalase in the apoptotic mechanism induced by apigenin in HepG2 human hepatoma cells. Chem Biol Interact. 2011; 193:180-189.

66. Sertel S, Tome M, Briehl MM, Bauer J, Hock K, Plinkert PK, Efferth T. Factors determining sensitivity and resistance of tumor cells to arsenic trioxide. PLoS One. 2012; 7:e35584.

67. Bechtel W, Bauer G. Catalase protects tumor cells from apoptosis induction by intercellular ROS signaling. Anticancer Res. 2009; 29:4541-4557.

68. Kovacevic Z, Richardson DR. The metastasis suppressor, Ndrg-1: A new ally in the fight against cancer. Carcinogenesis. 2006; 27:2355-2366.

69. Russo T, Zambrano N, Esposito F, Ammendola R, Cimino F, Fiscella M, Jackman J, O'Connor PM, Anderson CW, Appella E. A p53-independent pathway for activation of WAF1/CIP1 expression following oxidative stress. J Biol Chem. 1995; 270:29386-29391.

70. Huo JX, Metz SA, Li GD. p53-independent induction of p21(waf1/cip1) contributes to the activation of caspases in GTP-depletion-induced apoptosis of insulin-secreting cells. Cell Death Differ. 2004; 11:99-109.

71. Kovacevic Z, Sivagurunathan S, Mangs H, Chikhani S, Zhang D, Richardson DR. The metastasis suppressor, $\mathrm{N}$-myc downstream regulated gene 1 (NDRG1), upregulates p21 via p53-independent mechanisms. Carcinogenesis. 2011; 32:732-740.

72. Sarsour EH, Kalen AL, Goswami PC. Manganese superoxide dismutase regulates a redox cycle within the cell cycle. Antioxid Redox Signal. 2014; 20:1618-1627.

73. Sarsour EH, Kumar MG, Chaudhuri L, Kalen AL, Goswami PC. Redox control of the cell cycle in health and disease. Antioxid Redox Signal. 2009; 11:2985-3011.

74. Sarsour EH, Kalen AL, Xiao Z, Veenstra TD, Chaudhuri L, Venkataraman S, Reigan P, Buettner GR, Goswami PC. Manganese Superoxide Dismutase Regulates a Metabolic Switch during the Mammalian Cell Cycle. Cancer Res. 2012; 72:3807-3816.

75. Candas D, Fan M, Nantajit D, Vaughan AT, Murley JS, Woloschak GE, Grdina DJ, Li JJ. CyclinB1/Cdk1 phosphorylates mitochondrial antioxidant MnSOD in cell adaptive response to radiation stress. J Mol Cell Biol. 2013; 5:166-175.

76. Ubersax JA, Woodbury EL, Quang PN, Paraz M, Blethrow JD, Shah K, Shokat KM, Morgan DO. Targets of the cyclindependent kinase Cdk1. Nature. 2003; 425:859-864. 
77. Cabrera M, Gomez N, Remes Lenicov F, Echeverría E, Shayo C, Moglioni A, Fernández N, Davio C. G2/M Cell Cycle Arrest and Tumor Selective Apoptosis of Acute Leukemia Cells by a Promising Benzophenone Thiosemicarbazone Compound. PLoS One. 2015; 10:e0136878.

78. Choi HJ, Fukui M, Zhu BT. Role of cyclin B1/Cdc2 up-regulation in the development of mitotic prometaphase arrest in human breast cancer cells treated with nocodazole. PLoS One. 2011; 6:e24312.

79. Topham CH, Taylor SS. Mitosis and apoptosis: how is the balance set? Curr Opin Cell Biol. 2013; 25:780-785.

80. Saswati CA, Chakraborty A, Dash SP, Panda AK, Acharyya R, Biswas A, Mukhopadhyay S, Bhutia SK, Crochet A, Patil YP, Nethaji M, Dinda R. Synthesis, X-ray structure and in vitro cytotoxicity studies of $\mathrm{Cu}(\mathrm{I} / \mathrm{II})$ complexes of thiosemicarbazone: special emphasis on their interactions with DNA. Dalton Trans. 2015; 44:6140-6157.

81. Prachayasittikul VV, Prachayasittikul S, Ruchirawat S, Prachayasittikul VV. 8-Hydroxyquinolines: a review of their metal chelating properties and medicinal applications. Drug Des Devel Ther. 2013; 7:1157-1178.

82. Bal-Demirci T, Congur G, Erdem A, Erdem-Kuruca S, Özdemir N, Akgün-Dar K, Varol B, Ülküseven B. Iron(III) and nickel(ii) complexes as potential anticancer agents: Synthesis, physicochemical and structural properties, cytotoxic activity and DNA interactions. New J Chem. 2015; 39:5643-5653.

83. Wilson JT, Jiang X, McGill BC, Lisic EC, Deweese JE. Examination of the Impact of Copper(II) $\alpha-(\mathrm{N}$ )-Heterocyclic Thiosemicarbazone Complexes on DNA Topoisomerase II $\alpha$. Chem Res Toxicol. 2016; 29:649-658.
84. Pastuch-Gawołek G, Malarz K, Mrozek-Wilczkiewicz A, Musioł M, Serda M, Czaplinska B, Musiol R. Small molecule glycoconjugates with anticancer activity. Eur J Med Chem. 2016; 112:130-144.

85. Rao VA. Iron chelators with topoisomerase-inhibitory activity and their anticancer applications. Antioxid Redox Signal. 2013; 18:930-955.

86. Palchaudhuri R, Hergenrother PJ. DNA as a target for anticancer compounds: methods to determine the mode of binding and the mechanism of action. Curr Opin Biotechnol. 2007; 18:497-503.

87. Becker HC, Nordén B. DNA Binding Mode and Sequence Specificity of Piperazinylcarbonyloxyethyl Derivatives of Anthracene and Pyrene. J Am Chem Soc. 1999; 121:11947-11952.

88. Rao VA, Klein SR, Agama KK, Toyoda E, Adachi N, Pommier Y, Shacter EB. The iron chelator Dp44mT causes DNA damage and selective inhibition of topoisomerase IIA in breast cancer cells. Cancer Res. 2009; 69:948-957.

89. Yalowich JC, Wu X, Zhang R, Kanagasabai R, Hornbaker $\mathrm{M}$, Hasinoff BB. The anticancer thiosemicarbazones Dp44mT and triapine lack inhibitory effects as catalytic inhibitors or poisons of DNA topoisomerase II $\alpha$. Biochem Pharmacol. 2012; 84:52-58.

90. West DX, Liberta AE, Rajendran KG, Hall IH. The cytotoxicity of copper(II) complexes of heterocyclic thiosemicarbazones and 2-substituted pyridine N-oxides. Anticancer Drugs. 1993; 4:241-249.

91. Rahman I, Kode A, Biswas SK. Assay for quantitative determination of glutathione and glutathione disulfide levels using enzymatic recycling method. Nat Protoc. 2006; $1: 3159-3165$. 